\title{
ONGELMANA ONANIA
}

\section{Itsetyydytyksen patologisoinnin mikrotasoiset merkitykset 1930- luvun psykiatrisissa sairauskertomuksissa}

\section{Anna Kinnunen}

S eurauksina hallusinaatioita, hedelmättömyyttä ja itsetuhoisuutta. Hoitoina erilaisia dieettejä, kylmiä kylpyjä ja kirurgiaa. Muun muassa nämä seuraukset ja hoitokeinot liitettiin onaniaan eli itsetyydytykseen 1700-luvun alun ja 1900-luvun alkuvuosikymmenten välisessä yleiseurooppalaisessa tieteellis-yhteiskunnallisessa keskustelussa. Kristillisen kirkon piirissä itsetyydytyksen harjoittamista oli paheksuttu jo vuosisatojen ajan, mutta laajan ja miltei paniikinomaisen yhteiskunnallisen huomion kohteeksi onania nousi 1700-luvulla sitä koskevan lääketieteellisen kiinnostuksen heräämisen myötä. Itsetyydytys medikalisoitui ja muuttui synnistä sairaalloisen poikkeavaksi toiminnaksi, minkä kaiut kantautuivat onaniaan liittyvinä pelkoina ja häpeän tunteina syvälle 1900-luvulle saakka. (Laqueur 2003; Kontula 2009, 95-97; van Driel 2012.)

Erityisesti 1800-luvun länsimaisessa lääketieteessä mielisairaus uskottiin yhdeksi itsetyydytyksen vakavimmista seurauksista (Hare 1962; Hall 2003). 1900-luvulle tultaessa onanian sairaalloisia seurauksia koskevat tulkinnat limittyivät sekä yleiseurooppalaisessa että kotimaisessa keskustelussa rotuhygieeniseen diskurssiin, jossa itsetyydytys katsottiin osoitukseksi mielisairaiden henkisestä rappiosta ja epätavallisen voimakkaaksi uskotusta seksuaalivietistä (Mattila 1999, 125-126, 144, 295, 340; Hirvonen 2014, 191-192). Itsetyydytyksen ja mielisairauden välisen syy-seuraussuhteen konstruointi on yksi näkyvimmistä - mutta tabuluonteensa vuoksi myös yksi vähiten tunnetuista ja tarkastelluista - esimerkeistä psyykkisesti sairastavien ihmisten avoimesta toiseuttamisesta. ${ }^{1}$ Siihen nojaten mielisairaat sysättiin moraaliseen marginaaliin, eräänlaisiksi aktiivisiksi väärintekijöiksi, jotka olivat itse aiheuttaneet oman sairautensa sopimattomaksi ja vahingolliseksi luokitellulla toiminnallaan. Tässä artikkelissa tarkastelen mielisairaalapotilaiden

1 Kansainvälisessä tutkimuksessa aihe nostettiin esille antipsykiatrisen aallon aikana 1960-70-luvuilla (esim. Hare 1962; MacDonald 1967; Gilbert 1975). Suomessa aihetta on sivuttu historiantutkimuksen piirissä tarkasteltaessa itsetyydytykseen liittyneitä uskomuksia ja pelkoja (esim. Halmesvirta 1998, 221-245; Keskisarja 2011, 157-188). Käsitys itsetyydytyksestä nimenomaan mielisairauden aiheuttajana ja kyseisen syy-seuraussuhteen rakentumisen sosiokulttuuriset taustatekijät ovat kotimaisen tutkimuksen piirissä kuitenkin miltei tarkastelematon kenttä. 
itsetyydytyksen patologisoinnin mikrotasoisia merkityksiä 1930-luvun psykiatrisissa sairauskertomuksissa.

Olen käynyt läpi pohjoissavolaisen Niuvanniemen sairaalan ${ }^{2}$ potilaita koskevat sairauskertomukset 1930-luvulta. Kyseinen vuosikymmen muodostaa mielisairaalapotilaiden itsetyydytykseen ja seksuaalisuuteen liitettyjen käsitysten kannalta merkityksellisen kehyksen. Ensinnäkin katson 1930-luvun ajankohdaksi, jolloin mielisairaalapotilaiden seksuaalisuuteen kohdistuneet pelot ja kontrolli saavuttivat suomalaisessa yhteiskunnassa eräänlaisen huippunsa. Tästä konkreettisena esimerkkinä toimii mielisairaiden pakkosterilisoinnit mahdollistaneen lain hyväksyminen ja täytäntöönpano vuosikymmenen puolivälissä (ks. Mattila 1999, 274-338). Toisaalta onaniaa koskevat käsitykset olivat ajan yleiseurooppalaisessa mielisairaanhoidossa liikkeessä, sillä jyrkimmät näkemykset itsetyydytyksen ja mielisairauden kausaliteetista olivat jo vaimenneet (ks. Hare 1962, 9, 12-15; Hall 2003, 685-686). Lientynyt suhtautuminen oli rantautunut myös suomalaiseen mielisairaanhoitoon, jonka piirissä esitettiin 1930-luvun kynnyksellä näkemyksiä, joiden mukaan onanian harjoittaminen aiheutti vakavien mielisairauksien sijasta pikemminkin lievempiä psyykkisiä häiriöitä, kuten hermostuneisuutta (ks. esim. Neuman-Rahn 1924, 122-123). Vaikka lääketieteellinen kiinnostus onanian seurauksia kohtaan hiipui, käsitys itsetyydytyksen vahingollisuudesta eli kuitenkin yhä sitkeästi esimerkiksi pupulaarien kasvatus-, terveys- ja seksuaalioppaiden sivuilla (ks. esim. Stall 1928; ks. myös Kontula 2009, 97).

Noudatan mikrohistoriallista tutkimusstrategiaa (ks. Levi 1991; Suoninen 2001; Rantala 2009, 40-44). Nostan artikkelin primääriaineistoksi kaksi sairauskertomusta, joissa potilaan itsetyydytys on keskeisessä asemassa. Mikrohistorialliselle otteelle tyypillisesti suuntaan huomioni usein vaiettuun aiheeseen ja aikansa yhteiskunnassa marginaalisessa asemassa olleiden yksilöiden ja näiden omaisten näkökulmaan. Luen sairauskertomuksia suhteessa onaniasta käytyyn yleiseurooppalaiseen lääketieteellis-yhteiskunnalliseen keskusteluun, jonka tulkitsen arvo- ja normisidonnaiseksi poikkeavuuden konstruoinniksi. Sairauskertomukset muodostavat mikro- ja makrotasoja ristivalottavalle mikrohistorialliselle otteelle otollisen alustan, sillä ne sisältävät monenlaisia tekstejä ja näkökulmia. Yhtäältä ne koostuvat hoitohenkilökunnan laatimista, potilaan sairautta ja käyttäytymistä koskevista merkinnöistä, joissa kuuluu ajan psykiatrian ääni poikkeavuuden rajoja koskevaan keskusteluun aktiivisesti osallistuneena instituutiona. Toisaalta sairauskertomuksista heijastuu myös arkinen ja yksityinen näkökulma, sillä ne sisältävät esimerkiksi potilaan ja omaisten välistä kirjeenvaihtoa sekä toisinaan myös potilaan itsensä kirjoittamia, omaa elämää ja sairautta koskevia pohdintoja.

Teoreettisina työkaluinani hyödynnän medikalisaation, sosiaalisen kontrollin ja poikkeavuuden toisiinsa kietoutuvia käsitteitä. Onanian nousu laajan tieteellis-yhteiskunnallisen huomion kohteeksi liittyi medikalisaatioon eli länsimaisen lääketieteen

2 Sairaala perustettiin Kuopion Niuvanniemeen vuonna 1885. Se toimi 1950-luvulle saakka valtion keskusmielisairaalana, jonka tehtävänä oli vastata Itä-Suomen alueella akuuttia mielisairaalahoitoa tarvitsevista potilaista. Lisäksi tehtäviin kuului mielentilatutkimusten tekeminen ja kriminaalipotilaiden hoito. (Vuorio 2010, 15-29.) Nykyään Niuvanniemen sairaala toimii valtion oikeuspsykiatrisena sairaalana. 
sosiokulttuurisen aseman vahvistumiseen (ks. Conrad 1992; Tuomainen ym. 1999; Barnet 2012). Poikkeavuudella tarkoitan käyttäytymistä ja inhimillisiä ominaisuuksia, jotka rikkovat aikaan ja paikkaan kytkeytyviä, normaalia ja soveliasta määrittäviä rajoja (ks. Conrad \& Schneider 1980, 1-3, 5-7; Jokinen ym. 2012, 190-192, 197). Sosiaalisen kontrollin taas ymmärrän tavoiksi ja välineiksi, joiden avulla poikkeavuutta pyritään käsittelemään ja sanktioimaan (ks. Zola 1972; Conrad \& Schneider 1980,7$)$. Itsetyydytyksen muuttuminen synnistä sairaalloisen poikkeavaksi - toisin sanoen patologiseksi - toiminnaksi on yksi havainnollisimpia esimerkkejä medikalisaatioprosesseista, joiden myötä valta määritellä, käsitellä ja kontrolloida poikkeavuutta siirtyi kirkon piiristä lääketieteen kentälle. Toisaalta onaniaa koskevien käsitysten kulttuurihistoria on myös kenties täydellisin esimerkki demedikalisaatiosta eli kehityskulusta, jossa aikanaan sairaalloisen poikkeavaksi luokiteltu toiminta muuttui 1900-luvun jälkipuolella normaaliksi ja edelleen nykyaikaan tultaessa jopa suositeltavaksi ja terveelliseksi. (Conrad 2007, 7, 97, 120; ks. myös Kontula 2009, 95-97.)

Psykiatrian asemaa sosiaalisen kontrollin haltijana on pohdittu Michel Foucault'n viitoittamissa tulkinnoissa. Foucault'laisessa ajattelussa mielisairaalalaitos on nähty, esimerkiksi vankeinhoitolaitoksen ohella, modernien yhteiskuntien virallisena kontrollijärjestelmänä, jonka piirissä potilaisiin suhtaudutaan yhteiskunnallisen järjestyksen uhkina. Hoitokeinot on tällöin ymmärretty kurinpidon välineiksi, joiden kautta potilaita ja näiden ruumiita kontrolloidaan ja sanktioidaan sekä edelleen saatetaan järjestykseen ja normalisoidaan. (Ks. Foucault 2000, 261, 411, 418; ks. myös Cohen 1985, 13-39.) Myös tässä artikkelissa ymmärrän 1930-luvun suomalaisen mielisairaanhoidon merkittäväksi ja aktiiviseksi sosiaalisen kontrollin haltijaksi, mutta suuntaan huomioni mikrotasolle - siihen, millaisia johtolankoja aineistosta on nähtävissä itsetyydytyksen patologisoinnin henkilökohtaisista merkityksistä. Kysyn, millaisia poikkeavuuden ulottuvuuksia onaniaan liitetään mikrotasolla ja miten potilaat ja/tai potilaan omaiset itse osallistuvat itsetyydytyksen patologisuutta koskevien tulkintojen konstruointiin.

Artikkelini paikantuu ajankohtaiseen humanistis-yhteiskuntatieteelliseen hulluustutkimukseen, jossa tarkastellaan sairauden ja poikkeavuuden määrittymisen historiallisesti ja kulttuurisesti muuntuvia käytänteitä (esim. Ahlbeck-Rehn 2006; Ussher 2012; Ahlbeck 2015; ks. myös Kinnunen \& Hänninen 2016). Folkloristiikassa ja perinteentutkimuksessa aihetta on lähestytty yhteisöissään poikkeaviksi katsottujen yksilöiden ja näistä kerrotun folkloren kautta (esim. Saarinen 2003), mutta viime aikoina alalla on syntynyt myös tutkimusta, jossa huomio on normaalin ja patologisen välisessä rajankäynnissä (esim. Kinnunen 2016; Koski 2016). Perinteentutkimuksen vahvuus hulluustutkimuksen saralla on yksilön kokemuksen esille nostamisessa sekä toisaalta sen osoittamisessa, miten henkilökohtaiset tulkinnat sairaudesta ja poikkeavuudesta rakentuvat osana ajattelun ja kerronnan makrotasoisia ja usein pitkäkestoisia konventioita. Myös perinteentutkijalle ominainen herkkyys erilaisten tekstien ja äänien huomioimiselle korostuu luettaessa aineistoja, kuten tässä tapauksessa psykiatrisia sairauskertomuksia, joissa tulkintaa on rakennettava erityyppisten tekstien ja näkökulmien jännitteisenä palapelinä. 


\section{SYNNISTÄ (MIELI)SAIRAUDEN SYYKSI JA OIREEKSI}

Luon aluksi katsauksen itsetyydytyksen patologisoinnin historiaan, jossa kääntyi uusi sivu 1700-luvulle tultaessa. Uudenlaisen ajattelun konkreettisena airuena pidetään Lontoossa 1700-luvun alussa ilmestynyttä pamflettia Onania, or the Heinous Sin of Self-Pollution. ${ }^{3}$ Tekstin anonyymi kirjoittaja käsitteli itsetyydytystä yhä pääasiassa syntinä, kuten kristillinen kirkko ${ }^{4}$ oli tehnyt jo vuosisatojen ajan, mutta tekstistä teki poikkeuksellisen se, että kirjoittaja uskoi kyseisen synnin johtavan vakaviin terveydellisiin ongelmiin, kuten hedelmättömyyteen, impotenssiin ja epilepsiaan. (Hare 1962, 2; Neuman 1975, 2.) Ensimmäinen kirjoittaja, joka käsitteli onaniaa täysin lääketieteellisenä ongelmana, oli sveitsiläislääkäri Samuel Tissot, joka perusteli onanian epäterveellisyyttä humoraalioppia mukailevalla selityksellä, jossa ruumiinnesteiden epätasapaino - onanian kohdalla siemennesteen tuhlaaminen - korreloi vastaavasti ruumiinvoimien epätasapainona ja heikkenemisenä. Lisäksi onanian vaatima energia kuormitti Tissot'n mukaan hermostoa, mikä taas vahingoitti aivoja. Hän laati aiheesta väitöskirjan, joka ilmestyi vuonna 1758 ja käännettiin useille eurooppalaisille kielille. Viimeisin uusintapainos teoksesta otettiin vuonna 1905, mikä osaltaan kielii onanian uskottuja terveyshaittoja koskevan mielenkiinnon laajuudesta ja pitkäkestoisuudesta. (Hare 1962, 2-3; MacDonald 1967, 427-428; van Driel 2012, 83-84.)

1800-luvulle tultaessa käsitys onanian ja sairauden yhteydestä oli vakiintunut osaksi yleiseurooppalaista lääketiedettä. Samalla yleistyivät myös näkemykset, joissa onaniaa käsiteltiin vakavaan mielisairauteen johtavana ongelmana. (Hare 1962, 3; Neuman 1975, 5; Hall 2003, 688.) E. H. Hare on esittänyt klassikkoartikkelissaan Masturbatory Insanity: The History of An Idea (1962) kolme käytännöllistä syytä, miksi onania yhdistettiin leimallisesti juuri psyykkiseen sairauteen. Mielisairaat masturboivat usein avoimesti, ja mielisairaalat, joiden lukumäärä oli 1800-luvulla jatkuvassa kasvussa, tarjosivat otollisen kentän onanian ja sen harjoittajien havainnoimiseksi. Toiseksi usko noituuteen hulluuden selityksenä oli vähenemässä, minkä seurauksena syntynyttä tyhjiötä onanian ja mielisairauden kytköstä perustelevat, kansantajuiset teoriat osaltaan täyttivät. Anatomian tutkimuksen kehitys taas lisäsi mielenkiintoa sairauksien somaattisia syy-seuraussuhteita kohtaan myös mielisairaanhoidon saralla. (Hare 1962, 11-12.)

Äärimmäisissä näkemyksissä onanian uskottiin johtavan masturbaatiohulluuteen (engl. masturbatory insanity). Sen ensioireiden kuvailtiin näkyvän ulkonäön ja

$3 \quad$ Kuten pamfletin nimi osoittaa, itsetyydytystä nimitettiin pääasiassa onaniaksi tai itsesaastutukseksi. Eritoten onania oli yleisesti käytössä itsetyydytykseen viittaavana (tieteellisenä) nimityksenä vielä 1900-luvun alussa; esimerkiksi 1930-luvun suomalaisessa psykiatriassa itsetyydytykseen viitattiin onaniana. Käytän jatkossa pääasiassa nimitystä onania, erityisesti aineistoa analysoidessani. Itsetyydytyksellä ja onanialla viitataan samaan toimintaan, mutta käsitteinä ne kantavat erilaisia merkityksiä: itsetyydytykseen kytkeytyy verrattain myönteisiä, hyväksyttyyn ja terveenä pidettyyn seksuaalisuuteen liittyviä ulottuvuuksia, kun taas onania kantaa sairaalloiseen ja sopimattomaan seksuaalisuuteen kiinnittyviä merkityksiä. Analysoimissani sairauskertomuksissa konstruoidaan käsityksiä nimenomaan onaniasta.

4 Vaikka kirkko yhtäältä paheksuikin itsetyydytystä, toisaalta se suhtautui onaniaan syntinä syntien joukossa nostamatta sitä erityisesti esille. Kirkon piirissä itsetyydytys nähtiin pääasiassa munkkien ja yksinäisten aikuisten miesten paheena, joka herätti huomattavasti vähemmän huolta ja huomiota kuin esimerkiksi insesti tai sodomia. (MacDonald 1967, 430; Laqueur 2003, 124-125; ks. myös Keskisarja 2011, 159, 168.) 
persoonallisuuden muutoksissa: aluksi esimerkiksi aknena, kalpeutena ja keskittymisongelmina, sitten itsekkyytenä, synkkyytenä ja hermostuneisuutena. Mielisairauden puhjettua vaarana oli nopea dementoituminen ja itsetuho. (Hare 1962, 6-8; ks. myös Hall 2003.) Suomeen käsitys onanian ja mielisairauden kausaliteetista levisi muun muassa käännöskirjallisuuden kautta. Esimerkiksi ruotsalainen lääketieteen tohtori E. W. Wretlind kuvailee vuonna 1893 suomennettuna ilmestyneessä teoksessaan Miesten siitinelo säännöllisessä ja kivulloisessa tilassa onanian harjoittajan olemusta, käytöstä ja mielisairauden kehittymistä seuraavasti:

[Onanistin] voi tuntea vaalakanharmaasta kasvonsävystä, raukeista, sinisten rengasten ympäröimistä silmistä, veltosta, hervakasta käynnistä, kylmistä jaloista ja käsistä, jotka usein tuntuvat kosteilta, kylmänhikeviltä. Jonkunlainen taipumus potemaan ihonäppyjä, n. s. "finnejä" on myös tavallista. (Wretlind 1893, 88.)

[H]änestä tulee todellinen ihmisvihaaja, kaikkialla näkee hän vain synkkää - -. Hän on epätoivoinen oman itsensä, tulevaisuutensa ja vihdoin kaiken muunkin suhteen. Jos tähän lisäksi vielä sattuu ulkoisia vastoinkäymisiä tai jos omatunto heräjää, silloin tulee tämmöisestä apeamielisestä oikea synkkämielinen mielisairas. - - Joskus näemme semmoisen mielensairauden puhkeavan hurjamaisiksi raivon puuskauksiksi, jolloin potilas on hillimätön huimapää, törkeä sanoissaan ja töissään sekä raju hävittämiskiihkoinen, jonka vuoksi hänet täytyykin sulkea hourujen kammioihin. (Wretlind 1893, 93.)

Nimiölehdelle painetun huomautuksen mukaan Wretlindin teos on suunnattu "miehille ja äideille". Huomautuksessa kiteytyy onaniaa koskevalle keskustelulle tyypillinen piirre: suurin huomio ja huoli kohdistettiin nuoriin miehiin, ja äidit taas asetettiin lastensa seksuaalimoraalin mikrotasoisiksi kontrolloijiksi. Wretlindin teos onkin seksuaali- ja kasvatusopas, ja sen sivuilla usko onanian ja mielisairauden patologiseen yhteyteen eli ja voi hyvin. Laajassa länsimaisen lääketieteen kehyksessä valtasivat 1800-1900-lukujen taitteessa kuitenkin alaa jo uudenlaiset tulkinnat. Lääketieteen kehitys nakersi vähitellen pohjaa onanian ja vakavan (mieli)sairauden kausaliteetilta, sillä sen myötä esimerkiksi selkärankatuberkuloosin syyksi paljastuivat, onanian sijasta, mikroskoopein havaittavat bakteerit (Laqueur 2003, 51, 363). Vakavan mielisairauden sijasta onanian esitettiin kuitenkin edelleen aiheuttavan neurooseja, hermostuneisuutta ja erilaisia pelkotiloja (Hare 1962, 9, 12-15; Hall 2003, 685-686.)

Suomalaiset mielisairaanhoidon ammattilaiset pitivät yllä kansainvälisiä yhteyksiä (ks. Hirvonen 2014), ja myös onanian patologisuutta koskeva tieteellinen keskustelu tunnettiin. Mielisairaanhoitajille suunnatussa oppikirjassa Sielullisesti sairas ihminen ja hänen hoitonsa (1924) onaniaa käsitellään häiriönä "suvunsäilytys- eli sukuvietissä". Teoksessa onania esitetään mielisairauteen johtavan teon sijasta joko mielisairauden oireena tai toimintana, jonka vahingollisuus piili sen aikaansaamissa tuskan, häpeän ja syyllisyyden tunteissa:

Tämä itsetyydytysvietti eli itsesaastutus on jo lapsuudessa tavallinen ilmiö. Mutta jos himo herää liian aikaisin, on sitä pidettävä merkkinä sairaalloisista taipumuksista, ja lapsen on jouduttava lääkärin hoitoon. Himosta voi tulla mahti, joka vaatii itselleen ylen määrin fyysillisiä ja psyykillisiä voimia. Vaara piilee onanian aiheuttamassa reaktiossa, tuskassa, hermostuneisuudessa, häpeän- ja syyllisyydentunnossa 
eikä niinkuin tavallisesti luullaan itse teossa. Käyvän mielipiteen mukaan on onania syypää moniin mielitauteihin. Niin ei kuitenkaan ole asian laita. Se on visseissä taudinmuodoissa ensimmäinen merkki alkavasta mielitaudista, mutta ei missään tapauksessa sen syy. (Neuman-Rahn 1924, 122-123.)

Sitaatti on osin ristiriitainen, sillä vaikka onania nimetäänkin jo lapsuudessa tavalliseksi ilmiöksi, sitä kohtaan liian varhain herännyt himo kuvataan sairaalloiseksi, lääkärinhoitoa vaativaksi tilaksi. Tekstistä on kuitenkin nähtävissä, että 1900-luvun alkuvuosikymmeninä myös suomalaisessa mielisairaanhoidossa oli omaksuttu aiempaa neutraalimpia näkökulmia itsetyydytyksen seurauksiin.

Vaikka lääketieteellinen kiinnostus onanian seurauksia kohtaan hiipui 1900-luvulle tultaessa, onania sinänsä säilytti merkityksellisen asemansa sekä yleiseurooppalaisen että kotimaisen mielisairaanhoidon diskurssissa. Onaniaa koskevat tulkinnat limittyivät 1900-luvun alussa kuumentuneeseen rotuhygieeniseen keskusteluun, joka rantautui suomalaiseen lääketieteeseen, psykiatriaan ja julkiseen keskusteluun pääasiassa Keski-Euroopan ja muiden Pohjoismaiden kautta. Rotuhygieeniseen ajatteluun kuului käsitys inmissuvun henkisestä ja fyysisestä rappeutumisesta, degeneraatiosta. Mielisairaat nähtiin, muun muassa rikollisten ohella, ongelmallisena ja degeneroituneena ihmisryhmänä, joka oli vaarassa periyttää sairautensa sukupolvelta toiselle. Pelkoa ruokki se, että mielisairaat katsottiin usein paitsi epätavallisen seksuaalisiksi myös hämmästyttävän sikiäviksi. Skenaariona oli, että degeneroituneiden määrä kasvaisi näiden kurittoman seksuaalisuuden ja lisääntymisen kautta, mikä taas johtaisi vakaviin väestöpoliittisiin ongelmiin ja lopulta, pahimmassa tapauksessa, kansakunnan ja koko inmissuvun taantumiseen. Onania ei ollut rotuhygieenisen keskustelun ytimessä, sillä se ei ollut vaarassa johtaa hedelmöittymiseen ja ei-toivottujen ainesten periytymiseen. Taipumusta onanian harjoittamiseen pidettiin kuitenkin osoituksena mielisairaiden kurittomasta, moraalittomasta ja potentiaalisesti vaarallisesta seksuaalivietistä. (Mattila 1999, 34, 90, 125-126, 144, 295, 340; Hirvonen 2014, 191-192.)

\section{"Oikein normaali ei potilas ole koskaAn ollut" - poikkeavuus, SOSIAALINEN KONTROLLI JA MEDIKALISAATIO}

Tarkastelen onanian ja mielisairauden kausaliteettia arvo- ja normisidonnaisena poikkeavuuden konstruointina. Määrittelen poikkeavuuden inhimillisiksi piirteiksi, ominaisuuksiksi sekä olemisen ja toiminnan ulottuvuuksiksi, jotka rikkovat kulttuurisia normeja ja odotuksia. Poikkeavuus on aina kontekstisidonnaista, ja siten mikään yksilöissä, ryhmissä tai niiden toiminnassa ei itsessään ole poikkeavaa. Kyse on ulkopuolisesta, aikaan ja paikkaan kiinnittyvästä määrittelyprosessista, joka kohdistuu usein ylhäältä alaspäin, keskuksista marginaaleihin eli niihin, joiden mahdollisuudet osallistua yhteiskunnalliseen keskusteluun ja päätöksentekoon ovat vähäiset. (Kitsuse 1962, 248; Conrad \& Schneider 1980, 1-3, 5-7; Jokinen ym. 2012, 190-192, 197.) Edellä tiivistämässäni, onaniaa koskevassa tieteellis-yhteiskunnallisessa keskustelussa onanian harjoittaminen määrittyi sairaalloisen poikkeavaksi toiminnaksi, joka koetteli normaalin, soveliaan ja terveen (seksuaali-) käyttäytymisen rajoja. Edelleen se liitettiin psyykkisesti sairastaviin ihmisiin, joiden sosiaalinen asema oli jo ennestään heikko. 
Poikkeavuutta säädellään sosiaalisen kontrollin avulla. Ymmärrän sosiaalisen kontrollin keinoiksi, joiden avulla yksilöt, yhteisöt ja yhteiskunnat käsittelevät, normalisoivat ja sanktioivat poikkeavuutta. Sosiaalinen kontrolli toimii vastavuoroisesti sekä makro- että mikrotasolla: yhtäältä virallisten instituutioiden määrittäminä lakeina, sääntöinä ja suosituksina, toisaalta yksilöiden sosiaalistumisen myötä omaksumina tapoina, arvoina ja normeina sekä itseen ja kanssaihmisiin kohdistuvana tarkkailuna. (Conrad \& Schneider 1980, 7; Cohen 1985, 3.) Ihmisten käyttäytymistä säätelevä institutionaalinen valta oli vuosisatoja kristillisen kirkon hallussa, mutta modernisoitumisen ja sekularisoitumisen myötä tilanne muuttui. Valta määritellä ja käsitellä poikkeavuutta siirtyi yhä enenevissä määrin lääketieteen piiriin. (Conrad 1992, 213-214; Tuomainen ym. 1993, 24.)

Medikalisaatiota eli lääketieteellistymistä koskeva tieteellinen keskustelu virisi 1970-luvulla. Irving Kenneth Zolan (1972) ja Ivan Illichin (1975) kirjoitukset valoivat perustan kriittiselle näkökulmalle, jossa problematisoidaan länsimaisen lääketieteen asemaa sosiaalisen kontrollin haltijana. Painotan medikalisaatioon liittyvää arvottavaa ja moralistista ulottuvuutta, jonka myötä yhä useampia inhimillisiä ominaisuuksia ja eroavaisuuksia on alettu käsitellä sairaalloisina ongelmina. Äärimmäisissä tapauksissa patologisoiva katse on kohdistunut sellaisiin käyttäytymisen muotoihin tai kokonaisiin ihmisryhmiin, joiden on katsottu uhkaavan vallitsevia arvoja ja järjestystä. (Conrad 1992; Tuomainen ym. 1999, 15, 26, 30, 41; ks. myös Koski 2016, 13-19.) Medikalisaatiossa onkin ollut kyse myös vallankäytöstä ja pyrkimyksestä kontrolloida ja eliminoida tiettyjä ominaisuuksia, yksilöitä ja ryhmiä määrittelemällä ne sairaalloisiksi ongelmiksi. Esimerkiksi rotuhygieniassa, joka oli leimallisesti lääketieteen ammattilaisten johtama liike, pyrittiin tarjoamaan medikaalisia ratkaisuja 1800-1900-lukujen taitteen länsimaisten yhteiskuntien polttaviin sosiaalisiin ongelmiin (Mattila 1999, 147, 347). Mielisairaanhoidon kehyksessä medikalisaation moralistinen ulottuvuus on toteutunut näkyvästi myös homoseksuaalisuuden patologisoinnin kohdalla (ks. De Block \& Adriaens 2013).

1900-luvun alkuvuosikymmenten suomalaisessa mielisairaanhoidossa oli osaltaan kyse poikkeavuuden sosiaalisesta kontrollista. Mukailen Markku Salon (1996) näkemystä, jonka mukaan modernisoituvat yhteiskunnat tuottivat mielisairaalapotilaasta ihanteellisen kansalaisen vastakohtaa, mallimuukalaista. Laitoshoitoon suljetun mielisairaalapotilaan tehtävänä oli toimia varoittavana esimerkkinä siitä, mihin valitsevien arvojen ja normien vastainen käyttäytyminen voi äärimmillään johtaa. (Salo 1996, 49-50; ks. myös Kirkebæk 2005, 196, 197, 203.) Salon näkemys on kärkevä, mutta se on perusteltavissa psykiatrian aikalaisdiskurssia tarkastelemalla. Rotuhygieeninen ajattelu ja siihen liittynyt degeneraation pelko olivat 1900-luvun alun suomalaisessa mielisairaanhoidossa vahvassa asemassa (ks. esim. Ahlbeck ym. 2013, 11-10). Tämä näkyy selkeästi myös Niuvanniemen potilaista ja näiden omaisista kirjatuissa huomioissa:

[Potilaan] isässä on ollut mielisairautta lievemmässä muodossa, setä aivan paha mielisairas, sisaret ja veljetkään eivät ole normaalikunnossa, äitikin vähän omituinen luonteeltaan. (Kansallisarkisto, Niuvanniemen sairaan arkisto, sairauskertomus nro 520/1933.) 
Anna Kinnunen: Ongelmana onania

[http://www.elore.fi/arkisto/2_17/kinnunen.pdf]

[P]otilaan äiti ajoittain, erittäin[kin] keväisin hermostunut. Potilaan isä ja isän suku äksypäistä. Äiti ajoittain abnormi. (354/1936.)

[Potilaan] isä omituinen ja kulkee hieman hassahtavan kirjoissa. Äiti kiukkuinen. (486/1939.)

Potilaan isän veljen poika suuri laiskuri, melkein mielisairas (600/1939).

Oikein normaali ei hän [potilas] ole koskaan ollut: lapsesta saakka ollut - - hyvin itsepäinen ja ilkeä; koulunkäynti ollut vaikeaa; onaniaa on hän harjoittanut 6 kuukauden vanhasta asti. (378/1935.)

Sitaateissa kertautuvat samankaltaiset, arvottavat ilmaukset, kuten "omituinen" ja "abnormi". Ilmauksista heijastuu aikakauden mielisairaanhoidolle tyypillinen huoli ei-toivottujen ominaisuuksien perinnöllisyydestä ja siihen liittyvästä perheiden, sukujen ja kansakunnan rappeutumisesta. Viimeisessä lainauksessa otetaan esille myös varhaislapsuudessa alkanut onania, minkä avulla perustellaan näkemystä, jonka mukaan kyseinen potilas ei ole koskaan ollut "oikein normaali". Esimerkit osoittavat konkreettisesti, kuinka 1900-Ivun alkuvuosikymmenten suomalaisessa mielisairaanhoidossa oli kyse paitsi terveyden ja sairauden myös normaaliuden ja poikkeavuuden määrittelystä ja käsittelystä. Psykiatrian aikalaisdiskurssissa potilas määrittyi usein rappeutuneeksi ja "omituiseksi" toiseksi, eräänlaiseksi yhteiskunnan mallimuukalaiseksi, joka rikkoi normaalin, ihanteellisen ja hyväksytyn käyttäytymisen rajoja esimerkiksi onanian harjoittamisen kautta.

\section{Poikkeavaa ja tyypillistä: aineistona Eeron ja Matin SAIRAUSKERTOMUKSET}

Olen lukenut Niuvanniemen sairaalan potilaiden sairauskertomukset vuosilta 19301939, yhteensä noin 1800 potilaan tiedot. Primääriaineistona käytän kahden potilaan, Eeron ja Matin, sairauskertomuksia. ${ }^{5}$ Kirjautuessaan sairaalaan 1930-luvulla Eero oli reilun kahdenkymmenen ja Matti vajaan kolmenkymmenen vuoden iässä. Eero oli naimaton opiskelija, jonka laitoshoitojakso kesti vuosia. Matti taas oli työssäkäyvä, naimisissa oleva mies, joka viipyi potilaana verrattain lyhyen ajanjakson. Laitoshoitonsa aikana molemmat miehet saivat toisistaan eroavan psykiatrisen diagnoosin, mutta heidän sairauskertomuksiaan yhdistää yksi merkityksellinen tekijä: onaniaa koskevat merkinnät. ${ }^{6}$

Kyseisten sairauskertomusten esille nostaminen on osin mikrohistoriallisen tutkimusstrategian, osin aineistokokonaisuuden luonteen sanelema valinta. Eeron

$5 \quad$ Eero ja Matti ovat peitenimiä. Heidän sairauskertomuksensa sisältävät terveydentilaa ja seksuaalisuutta koskevia merkintöjä, jotka henkilötietolaki määrittelee arkaluonteisiksi tiedoiksi. Sairauskertomuksia siteeratessani ja referoidessani olen poistanut tekstistä suorat ja epäsuorat tunnistetiedot. Tuon Eeron ja Matin elämänkulkua ja sairauskertomusten yksityiskohtia esille siinä määrin kuin se on tulkinnan kannalta välttämätöntä mutta niin, että potilaiden anonymiteetti ei kuitenkaan vaarannu.

6 Luen Eeron ja Matin sairauskertomuksia onanian merkityksellistämisen näkökulmasta, mikä korostaa onanian merkitystä kyseisissä sairauskertomuksissa. Huomautan, että onania ei kuitenkaan ollut syy Eeron ja Matin laitoshoidolle. Molemmilla miehillä oli psyykkinen sairaus, jolle määritettiin virallinen psykiatrinen diagnoosi. En tuo potilaiden diagnoosia tai siihen liittyviä yksityiskohtia esille yhtäältä eettisistä ja toisaalta näkökulmavalinnastani johtuvista syistä. 
ja Matin sairauskertomukset kiinnittivät huomioni lukiessani aineistoa alun perin toisenlaisesta näkökulmasta. ${ }^{7}$ Aineistossa toistui merkintöjä potilaiden seksuaalisuudesta, myös onaniasta, mutta laajassa mittakaavassa onaniaa käsitellään ainoastaan Eeron ja Matin kohdalla. Kuvaava esimerkki on, että erään nuoren miespotilaan sairauskertomuksesta löytyy yksi onaniaan liittyvä maininta: tehtäessä selkoa potilaan perhesuhteista ja mahdollisesta sukurasituksesta potilaan isän on kirjattu harjoittaneen "nuorena jonkunverran onaniaa" (644/1939). Merkintöjä potilaan itsensä harjoittamasta onaniasta ei sen sijaan löydy. Sairauskertomuksista onkin nähtävissä viitteitä siitä, että suomalaisen psykiatrian mielenkiinto potilaiden itsetyydytystä tai vähintäänkin sen seurauksia kohtaan oli laantumassa laajamittaisesta huomiosta yksittäisiksi hajanaisiksi maininnoiksi. Tätä taustaa vasten Eeron ja Matin sairauskertomukset nousivat esille poikkeuksina, joissa potilaan harjoittama onania on näkyvästi ja toistuvasti esillä.

Tulkitsen Eeron ja Matin sairauskertomuksia tyypillisinä poikkeuksina. Mikrohistoriallisessa otteessa huomio kohdistetaan toistuvuuden sijasta poikkeuksellisiin, huomiota herättäviin yksityiskohtiin. Parhaimmassa tapauksessa pienet, näennäisen poikkeavat yksityiskohdat toimivat johtolankoina makrotasolle ja paljastavat ajalle, yhteiskunnalle ja kulttuurille tyypillisiä ajattelutapoja sekä mahdollisia piileviä jännitteitä ja muutosprosesseja. (Ginzburg 1996, 74, 103, 180-181, 185; Peltonen 1999, 62-64.) Mikrohistoriallista tutkimusta ohjaa myös näkemys, jonka mukaan poikkeuksellisen ja tyypillisyyden raja on liukuva ja jokainen yksilö on samanaikaisesti molempia näkökulmasta ja kontekstista riippuen (Elomaa 2001, 71-72; Rantala 2009, 42). Vaikka Eeron ja Matin sairauskertomukset nousivat 1930-luvun sairauskertomusten kontekstissa esille poikkeuksina, suhteessa laajempaan yhteiskunnalliseen kehykseen niistä on hahmotettavissa myös tyypillisiä ajattelutapoja, kuten seksuaalisuuteen ja mielisairaisiin kohdistuneita uskomuksia ja pelkoja. On myös syytä olettaa, että vaikka onania onkin näkyvästi esillä vain kahdessa sairauskertomuksessa, se oli todellisuudessa tätä yleisempää niin mielisairaalapotilaiden kuin muun väestön keskuudessa. ${ }^{8}$ Poikkeavuuden ja tyypillisyyden ulottuvuudet kietoutuvat toisiinsa myös Eeron ja Matin sosiaalisen aseman kautta: mielisairaalapotilaina he edustivat aikansa marginaalia ja poikkeavuutta, mutta poikkeavuus ja siihen kohdistuneet määritykset ja toimenpiteet kertovat samalla tyypillisestä - siitä, mikä on kulloinkin katsottu normaaliksi, terveeksi ja ihanteelliseksi (ks. Elomaa 2001, 22; ks. myös Harjula 1996, 12, 199; Mattila 1999, 348).

Sairauskertomuksiin sisältyy erityyppisiä tekstejä. ${ }^{9}$ Niiden määrä ja laatu vaihtelevat potilaittain, mutta jokaisesta potilaasta on täytetty ainakin perustietolomake, johon on kirjattu muun muassa sairauden puhkeamista koskevat esitiedot, diagnoosi sekä tiedot sisään- ja uloskirjautumisen ajankohdista. Eeron ja Matin

$7 \quad$ Käsillä olevan artikkelin idea on aineistolähteinen. Se sai alkunsa kiinnittäessäni huomiota Eeron ja Matin sairauskertomuksiin samalla, kun luin aineistoa vanhenevan ruumiin ja mielen merkityksellistämisen näkökulmasta, josta työstä parhaillaan artikkelia.

8 Anssi Halmesvirta (1998, 221-245) on tarkastellut suomalaisen Terveydenhoitolehden lääkärinpalstalle vuosina 1889-1916 lähetettyjä kirjeitä ja niihin annettuja vastauksia. Huomattava osa palstalle lähetetyistä kirjeistä koski onanian harjoittamisen seurauksia. Aineistonsa perusteella Halmesvirta on päätellyt onanian olleen "monille nuorille todellinen ja vakava riippuvuus", jonka aiheuttamiin huoliin ja pelkoihin haettiin vastausta palstalle lähetettyjen kysymysten kautta. Esittelen ja pohdin tekstien ominaisluonnetta tarkemmin aineiston analyysin yhteydessä. 
sairauskertomukset sisältävät myös useita kerronnallisia tekstejä, kuten potilaan omaisten laatimia kirjeitä. Matin sairauskertomukseen sisältyy myös autoanamneesi (sairauskertomuksessa lat. autoanamnesis) eli potilaan itsensä laatima omaelämäkertamainen teksti, jossa Matti kertoo elämästään ja sairauden kehittymisestä omasta näkökulmastaan. Sairauskertomukset eivät itsessään muodosta yhtä yhtenäistä kertomusta, vaan esimerkiksi onaniaa koskevat maininnat ovat erityisesti Eeron sairauskertomuksessa hajallaan eri teksteissä paikoin suppeinakin mainintoina. Matin kohdalla onania on näkyvästi esillä ainoastaan potilaan laatimassa autoanamneesissa, mutta pohdin muiden tekstien hiljaisuutta merkityksellisenä yksityiskohtana, joka korostaa potilaan itsensä esittämiä tulkintoja.

Sairauskertomusten tarkasteluun liittyy vahva eettinen velvoite, joka ei rajoitu ainoastaan potilaiden anonymiteetin suojaamiseen. Mielisairaalapotilaina Eero ja Matti olivat aikanaan marginalisoituja inmisiä, joiden käytös, ruumis ja seksuaalisuus joutuivat toistuvan tarkkailun kohteiksi. Artikkelini nostaa potilaiden elämän ja seksuaalisuuden uudelleen tarkkailtaviksi ja suuntaa niihin valtaproblematiikkaan vääjäämättä kytkeytyvän tieteellisen katseen. (Ks. myös Ahlbeck 2015, 235.) Pyrin käsittelemään Eeron ja Matin sairauskertomuksia ymmärtäen ja kunnioittaen. Nostamalla heidän sairauskertomuksensa esille pyrin antamaan äänen kahdelle yksilölle, Eerolle ja Matille, jotka mielisairaalapotilaina edustivat aikanaan vaiennettua inmisryhmää. Tavoittelen analyysia, joka tuo potilaat esille inhimillisinä yksilöinä, joiden elämäntarinat, käyttäytyminen ja ominaisuudet eivät useinkaan vastanneet psykiatrisia potilaita, onanisteja tai muita ongelmallisiksi miellettyjä ihmisryhmiä koskevia stereotyyppisiä käsityksiä. Seuraavaksi siirryn Eeron ja Matin sairauskertomusten analyysiin.

\section{ONANISTI POIKKEAVANA YKSILÖNÄ}

Potilaan itsensä näkökulmasta onania määrittyy molemmissa sairauskertomuksissa ongelmalliseksi kiusaukseksi, jonka viettelevää kutsua kumpikaan miehistä ei kyennyt kontrolloimaan. Eritoten Erolle onania aiheutti häpeää ja voimakkaita tunnontuskia, mihin viittaavia johtolankoja on näkyvillä useissa sairauskertomukseen sisällytetyissä dokumenteissa, esimerkiksi niin kutsutuissa A- ja B-liitteissä. Mielisairaiden hoitoa koskeva laki edellytti, että laitoshoitopaikkaa haettaessa hakemukseen liitettiin potilasta koskevat esitietolomakkeet, joista A-liite oli useimmiten paikallisen kunnanlääkärin ja B-liite taas esimerkiksi kirkkoherran täyttämä. ${ }^{10}$ Eeron kohdalla kirkkoherra on kirjoittanut potilaan tähänastista elämää kartoittavan kysymyksen kohdalle muun muassa seuraavat tiedot: "Kasvatus hyvä; rippikoulun käynyt; harjoittanut itsesaastutusta; juoppoustaipumusta ei ole ollut."

10 Liitteet otettiin käyttöön vuoden 1889 mielisairaanhoitoa koskevan keisarillisen asetuksen myötä. A-liitteen täytti lähettävä lääkäri, kun taas B-liite edusti eräänlaista maallikkonäkökulmaa, sillä papin ohella sen saattoi täyttää esimerkiksi paikallinen nimismies tai kunnallislautakunnan esimies. B-liitteen kautta potilaan lähiyhteisö (asuinkunta) ilmoitti oman näkemyksensä potilaan henkilöhistoriasta, elintavoista ja sairauden taustasta. Virallisesti B-liite poistui käytöstä vuoden 1937 mielisairaslain muutoksessa, mutta joissakin tapauksissa lomaketta käytettiin 1930-luvun loppuun saakka. (Rissanen 2017.) Eritoten pappien täyttämänä kyseinen liite heijastaa kirkon asemaa yhteisöjen jäsenten käyttäytymisen ja ruumiin kontrolloijana. Sen välityksellä kirkko ja potilaan lähiyhteisö luovuttivat potilasta koskevat tietonsa mielisairaanhoidon käyttöön, mikä taas osaltaan kielii aikakauden psykiatrian auktoritatiivisesta asemasta poikkeavuuden rajoja määrittävänä instituutiona. 
Kysymykseen, "[o]nko tiettynä mitään syytä, jonka otaksutaan aikaansaaneen sairauden", kirkkoherra on kuitenkin vastannut kieltävästi. Kunnanlääkäri sen sijaan on kirjannut Eeron sairauden otaksuttavien syiden kohdalle lievän sukurasituksen, opinnoissa tapahtuneet vastoinkäymiset sekä onanian ja "siitä johtuvat tunnonvaivat". Eeron ajatustoiminnan kunnanlääkäri on kuvannut hätäiseksi, pelokkaaksi ja alakuloiseksi. Hänen mukaansa Eero mietti uskonnollisia asioita ja tunsi olevansa "hyvin syntinen".

Eeron kokema syntisyys oli seurausta onaniasta. Tilanne oli kärjistynyt itsemurhayritykseen ennen Niuvanniemen sairaalassa alkanutta laitoshoitojaksoa. Eeron isä kertoo poikansa itsemurhayrityksestä sairauskertomukseen liitetyssä kirjeessä, jonka hän on lähettänyt Niuvanniemen sairaalan lääkärille. Isä kirjoittaa matkustaneensa poikansa luokse saatuaan tiedon tapahtuneesta. Heti Eeron luokse saavuttuaan isä kysyi, miksi tämä oli yrittänyt riistää henkensä. Eero oli vastannut olevansa "niin suuri syntinen" ja tarkentanut, että "onania jota olen harjoittanut, on niin suuri synti, ettei voi elää". Kun isä myöhemmin kävi sairaalassa tapaamassa Eeroa, henkilökunta kirjasi potilaan taudinkulkua koskeviin tietoihin (sairauskertomuksessa lat. decursus morbi) huomautuksen, että Eero "ei ensin ruvennut puhelemaan isän kanssa, sanoi vain: 'paha poika, paha poika'". Sairauskertomuksen yksityiskohdista on nähtävissä, että Eeron sisältä kumpusi vahva tunne omasta poikkeavuudesta. Hän koki olevansa väärin ja sopimattomasti toimiva yksilö, epäonnistunut paha poika, joka ei kyennyt mielihalujensa ja kehonsa kontrolliin.

Kykenemättömyys itsekuriin oli yksi onanian harjoittamiseen liitetyistä ongelmallisista piirteistä. Kun onania nousi laajan lääketieteellis-yhteiskunnallisen huomion keskiöön valistuksen vuosisadalla 1700-luvulla, länsimainen ihmiskuva oli murroksessa. Moderni ihanneihminen oli rationaalinen, tiedonjanoinen ja hallittu sosiaalinen olento, mihin peilattuna onanistit näyttäytyivät vastakuvina: mielikuvituksen ja mielihalujensa vietävinä epäsosiaalisina toisina, jotka suuntasivat aikansa ja energiansa hyödyttömään, yksinäisyydessä tapahtuvaan toimintaan. (Laqueur 2003, 53, 204-205; van Driel 2012, 138-139, 191; ks. myös Gilbert 1975, 224-225.) Myös Eeron sairauskertomuksessa viitataan potilaan epäsosiaalisuuteen. Eeron äidin antamien tietojen mukaan pojalla oli ollut aina vain vähän tovereita ja tämä oli ollut lapsesta saakka "ihmisarka", minkä vuoksi poika olikin pääasiassa "pysytellyt vain kotona". Kirkkoherra taas on kirjannut B-liitteeseen huomautuksen, että Eerolla oli ollut "jonkunlaista arkuutta inmisiin nähden". Laitoshoitojakson aikana asia nostettiin esille. Eeron sairauden tilaa koskeviin huomioihin (sairauskertomuksessa lat. status praesens) on kirjattu lyhyt keskustelu, jonka mukaan henkilökunta oli tiedustellut Eerolta, oliko tämä ollut sellainen ihminen, joka on "kaihtanut ihmisiä". Eero oli vastannut kysymykseen myöntävästi: "Niinhän minä olen ollut."

Eeron kaltaisen nuoren miehen taipumus yksinäisyyteen vetäytymiseen oli moralistisesti arveluttava piirre, sillä onanistien uskottiin etsivän jatkuvasti "yksinäistä salaista paikkaa" paheensa harjoittamiseksi (ks. esim. Stall 1928, 61, 63). Eeron sairauskertomuksessa arkuutta ja hakeutumista yksinäisyyteen ei kuitenkaan suoraan yhdistetä onanian harjoittamiseen. Potilaan epäsosiaalisuutta koskevat huomiot ja kysymykset kuitenkin terävöittävät näkemystä 1900-luvun alkuvuosikymmenten suomalaisesta mielisairaanhoidosta toimijana, joka myös itsessään 
aktiivisesti etsi ja tuotti potilaidensa poikkeavuutta. Esimerkiksi kysymykset, joihin paikalliset kirkkoherrat, nimismiehet tai kunnallislautakuntien esimiehet vastasivat täyttäessään potilaan esitietoja kartoittavaa B-liitettä, ohjasivat etsimään ja näkemään potilaassa ja tämän lähipiirissä rappeutumisesta kieliviä "omituisia" piirteitä ja "turmiollisia" tapoja:

[Kysymys numero] 3. Onko mielisairautta, kaatuvatautia, luulotautia, hysteriaa, itsemurhia, luonnonlaadun, käytöksen tahi elämäntapain omituisuuksia, juoppoustaipumusta, rikoksia esiintynyt vanhemmissa tahi näiden lähimmissä sukulaisissa tahi sairaan sisaruksissa - -?

[Kysymys numero] 6. Sairaan edellinen elämä: hyvä tai leväperäinen kasvatus, ripilläkäynti - -, työskentely, varallisuuden tila, perheolot onnelliset tai onnettomat, onko sairas elänyt epäsäännöllisesti ja irstaasti, onko hänellä ollut turmiollisia tapoja, taipumusta juoppouteen - -?

Mikäli potilas oli osoittanut taipumusta onaniaan, 1930-luvun sairauskertomuksissa siihen viitattiin usein yksittäisenä mainintana vastauksessa jälkimmäiseen kysymykseen, jossa kartoitettiin laitoshoitoa edeltäviin elämänvaiheisiin ajoittuvia turmiollisia tapoja ja merkkejä irstaasta elämästä. Matin sairauskertomus on poikkeuksellinen, sillä siinä onania on näkyvästi esillä potilaan laatiman autoanamneesin myötä. Matin kirjoituksessa muistot omasta elämästä ja sen merkityksellisistä käänteistä suodattuvat onanian harjoittamisen kautta. Myös Matille onania oli paheellinen kiusaus, jonka vastustaminen kävi toistuvasti mahdottomaksi. Hän kirjoittaa oppineensa onanian harjoittamisen koulupoikana erään vanhemman miehen opastuksella. Seuraukset olivat Matin mukaan kielteisiä:

Seurauksena oli aivan huomattava lukuhaluni menettäminen sekä yksinäisyyteen vetäytyminen ja oireet hermostumiseeni. Samaa pahetta harjoitettiin koulupoikien keskuudessa sangen runsaasti ja niin ollen olin joukossa, enkä päässyt eroon paheestani, sitä suuremmalla syyllä kun minulla ei ollut vanhempia veljiä paikkakunnalla jotka olisivat voineet auttaa neuvoillaan. Sitäpaitsi, kun tuota pahetta harjoitettiin salassa ei luonnollisesti äitinikään saanut vihiä joten pahe pääsi juurtumaan sairaalloisuudeksi. ${ }^{11}$

Matti kirjoittaa, kuinka hänen positiiviset taipumuksensa, kuten lukuinto ja halu opiskella, katosivat ja korvautuivat onanian harjoittamisen myötä hermostuneisuudella ja epäsosiaalisuudella. Hänen näkemyksensä mukailee aikakauden lääketieteellis-moralistista diskurssia, jossa onanian varoitettiin johtavan aluksi yksinäisyyteen vetäytymiseen ja sitten vähintäänkin syyllisyydentuntoon, hyvien harrastusten hylkäämiseen ja hermostuneisuuteen (ks. esim. Stall 1928, 63). Edelleen Matti selittää onanian juurtuneen "sairaalloisuudeksi", koska eräänlaiset mikrotasoiset norminvartijat puuttuivat tai eivät osanneet sekaantua asiaan: vanhemmat veljet eivät asuneet samalla paikkakunnalla, ja Matin äiti taas ei ollut tietoinen poikansa onaniasta.

11 Matin ja Eeron sairauskertomuksista poimittujen sitaattien arkistolähde on "Kansallisarkisto, Niuvanniemen sairaalan arkisto, sairauskertomukset 1930-1939". En ilmoita viitteen loppuosaa tarkasti, sillä se koostuu potilasnumerosta ja vuodesta, jolloin henkilö on kirjattu sisään sairaalaan. Matin ja Eeron henkilöllisyyttä suojatakseni pidän sairaalaan sisäänkirjautumisen ajankohdan salassa. 
Edes onanian ja mielisairauden välistä syy-seuraussuhdetta uusintavan varoittavan esimerkin näkeminen ei auttanut Mattia irtaantumaan paheestaan pysyvästi. Hän kirjoittaa toimineensa noin viidentoista vuoden iässä koulun kesäloman ajan apulaisena mielisairaalassa, jossa hän kuvailee nähneensä "tarpeeksi hyviä esimerkkejä [siitä] mihin paheeni harjoittaminen voi johtaa". Tässä kohdin Matti asettuu uusintamaan onanian ja mielisairauden välistä patologista vuorovaikutussuhdetta, minkä konkreettisella näkemisellä oli onanian harjoittamista hetkellisesti tyynnyttävä vaikutus. Kun Matti syksyllä palasi kouluun ja muiden onaniaa aktiivisesti harjoittavien koulupoikien pariin, varoittavan esimerkin hillitsevä vaikutus hiipui ja kiusaus voitti jälleen. Hallitakseen ei-toivottua taipumustaan ja sen kielteisiä seurauksia Matti aloitti rauhoittavien lääkkeiden käytön: "[A]loin käyttämään luvattoman paljon lääkkeitä päästäkseni heti iltaisin uneen, jotta olisin säästynyt itsesaastutuskiusauksesta." Yritykset eivät tuottaneet pysyvää tulosta, vaan seurauksena oli kierre, jossa Matti lankesi ensin onaniaan ja sitten taas lääkkeisiin.

Eero ja Matti pyrkivät sanktioimaan ja normalisoimaan poikkeavuuttaan aktiivisin ja äärimmäisin keinoin: edellinen itsemurhayrityksellä, jälkimmäinen rauhoittavilla lääkkeillä. Itsetyydytystä patologisoivissa näkemyksissä onanian harjoittaja oli kuitenkin korostuneen passiivinen yksilö, ruumiiltaan ja moraaliltaan veltto ja laiska ihminen, joka ei joko osannut tai halunnut kanavoida potentiaaliaan itseään ja yhteisöään hyödyttävään toimintaan. Jo (mieli)sairaudet sinänsä nähtiin modernisoituvissa ja teollistuvissa länsimaisissa yhteiskunnissa ongelmiksi, sillä ne heikensivät ruumista ja rapauttivat yksilön työkykyä jarruttaen siten tuottavuutta ja yhteiskunnan vaurastumista (Mattila 1999, 33-34; Hirvonen 2004, 147; Ahlbeck ym. 2013, 9-10; ks. myös Foucault 2000, 39). Eeron ja Matin kaltaiset psykiatriset potilaat, joiden taipumuksiin onania yhdistettiin, olivat kaksinkertaisesti poikkeavia, sillä näkemys passiivisuudesta ja hyödyttömyydestä liitettiin myös onanian harjoittajiin (ks. Gilbert 1975, 224-225; Laqueur 2003, 51-52; van Driel 2012, 88).

Eeron sairauskertomuksessa uusinnetaan käsitystä hyödyttömästä mielisairaalapotilaasta. Kuten onaniankin suhteen, myös tässä kohdin näkemys poikkeavuudesta kumpuaa potilaasta itsestään. Eeron opinnot olivat keskeytyneet sairastumisen vuoksi, ja sairauskertomuksen yksityiskohdista on nähtävissä, että hän tunsi toimettoman olonsa mielisairaalassa ongelmalliseksi. Potilaan sairauden tilaa koskeviin merkintöihin on kirjattu, että Eero oli valittanut ajatustensa kiertävän kehää: "[Mielessä] [k]iertää ikäviä ajatuksia, semmoista pahaa vaan." Kysyttäessä, oliko potilaalla edelleen itsemurha-aikeita, Eero oli vastannut myöntävästi: "Kyllä, onhan niitä pitkin aikaa ollut, en ymmärrä mistä niitä tulee." Merkinnän perusteella Eero oli vaikuttanut hämmentyneeltä itsetuhoisista ajatuksistaan, mutta toisaalta hän oli kuitenkin samassa yhteydessä selittänyt niiden syyksi tunteen omasta hyödyttömyydestä. Eero oli kertonut hoitohenkilökunnalle, että häntä vaivasi se, "että kun on täällä [sairaalassa] tarpeettomasti [ja] ei saa mitään aikaan". Itsemurhan mahdollisuus asettuu jälleen Eeron itsensä harkitsemaksi äärimmäiseksi kontrollin välineeksi, jonka avulla potilas pyrki käsittelemään ja sanktioimaan poikkeavuuttaan. Eero oli herkkä nuori mies, jota vaivasi paitsi syyllisyys onaniasta myös korostunut tietoisuus oman olemisen, elämäntilanteen ja toiminnan - tai pikemminkin 
passiivisen toimettomuuden - poikkeavuudesta suhteessa henkilökohtaisiin ja yhteiskunnallisiin odotuksiin.

\section{Onania poikkeavana seksuaAlisuUden muotona}

Vaikka valistuksen aikakausi kiinnitti ihanneihmisen kuvaan aiempaa itsenäisempiä ja yksilöllisempiä piirteitä, yksinään suoritettu seksi ei kelvannut merkiksi yksilön itsellisyydestä vielä yli kahteen vuosisataan. Itsesaastutusta koskevat käsitykset alkoivat murtua ja muuntua tulkinnoiksi itsetyydytyksestä vasta 1960-70-luvuilla, jolloin asetelma kääntyi vähitellen päinvastaiseksi: itsekkyyden ja kurittomuuden sijasta masturbaatio nähtiinkin merkkinä yksilön myönteisestä riippumattomuudesta sekä kyvystä hallita ja kontrolloida omaa kehoaan. (Laqueur 2003, 277.) Eeron ja Matin nuoruudessa 1900-luvun alkuvuosikymmeninä masturbaatio katsottiin kuitenkin vielä narsistiseksi seksiksi, joka ei tähdännyt reproduktioon eikä siten tuottanut yhteistä hyvää väestönkasvun muodossa (ks. Gilbert 1975, 224-225).

Käsitys onaniassa tapahtuvasta itsekkäästä elämänvoiman tuhlaamisesta oli peräisin Raamatun tekstin tulkinnasta. Suomessa raamatullista esimerkkiä hyödynnettiin onaniasta varoittavana tarinana esimerkiksi opaskirjasessa Mitä pojan tulee tietää (1928), jossa onanisteja moralisoitiin muistuttamalla, kuinka "Jumala rankaisi kuolemalla Onan nimisen miehen samanlaisesta teosta" (Stall 1928, 61-62). Esimerkillä viitattiin Vanhan Testamentin 1. Mooseksen kirjan Onaniin, mieheen, joka perinteistä tapaa noudattaen solmi avioliiton leskeksi jääneen kälynsä kanssa. Avioliitossa syntyvä lapsi olisi luettu lesken entisen puolison eli Onanin veljen jälkeläiseksi, mutta Onan kieltäytyi siittämästä perillistä veljelleen. Hän ei suostunut yhtymään uuden vaimonsa kanssa vaan "antoi siemenensä mennä maahan". (1. Moos. 38:1-10.) Ilmauksella viitattaneen itsetyydytyksen sijasta pikemminkin keskeytettyyn yhdyntään, mutta erityisesti 1700-1800-lukujen Euroopassa Onanin nimi ja tarina yhdistettiin onaniaan ja norminvastaiseen seksuaalisuuteen. Onan ja hänen nimestään johdetut onanistit tuhlasivat siementään sen sijaan, että he olisivat harjoittaneet aviollista seksiä ja turvanneet perheen, suvun ja yhteisön jatkuvuutta. (MacDonald 1967, 431; Laqueur 2003, 15, 112-117; van Driel 2012, 126,128 ; ks. myös Halmesvirta 1998, 223, 245.)

1700-1800-lukujen läntisessä Euroopassa tapahtuneiden yhteiskunnallisten muutosten pelättiin aiheuttavan onanialle otollisen maaperän. Koulutuksen arvostus kasvoi, minkä seurauksena opintoihin, valmistumiseen ja taloudellisesti vakaan, perheellistymiselle suotuisan aseman hankkimiseen kului aiempaa pidempi aika. Näin ollen avioitumisikä nousi, mutta samalla esimerkiksi tyttöjen kuukautisten alkamisikä laski ja biologinen sukukypsyys saavutettiin yhä aikaisemmin. Lapsuuden ja avioitumisen väliin muodostui problemaattinen elämänvaihe, nuoruus, jossa sukukypsien mutta naimattomien tyttöjen ja erityisesti poikien epäiltiin olevan alttiina onanian kaltaisille seksuaalisille kiusauksille. (Neuman 1975, 1, 6-7, 8-9, 20-21; Hall 1992, 374.) 1800-luvun lopussa ruotsalainen lääketietieteen tohtori E. W. Wretlind tiivisti muuttuneen tilanteen seuraavasti:

[M]eidän sivistynyt yhteiskunta [aiheuttaa] yhä enemmin kelpoisuus-vaatimuksiaan kaikilla aloilla, joka [yhdessä] tuon aivan yltiömäisyydeksi huipistuneen 
Anna Kinnunen: Ongelmana onania

[http://www.elore.fi/arkisto/2_17/kinnunen.pdf]

teollisuuden aloilla syntyneen kilpailun kanssa tekee miehelle sitäkin vaikeammaksi päästä turvattuun taloudelliseen asemaan. Hyvin arveluttavalla tavalla työntyy täten - - naimisen mahdollisuus hämärään tulevaisuuteen tai jää kokonaan sikseen. (Wretlind 1893, 197.)

Naimattomana ollen täytyy useamman miehen tehdä suuremmassa tai vähemmässä määrässä vastarintaa luonnolle niin hyvin ruumiillisessa kuin henkisessä katseessa. Kun mies on kypsynyt naimakelpoiseksi, niin on hänellä luonnollisesti sukuviettikin silloin voimakkain. (Wretlind 1893, 198.)

Käsitys nuorten miesten voimakkaasta sukuvietistä eli edelleen vahvana Eeron ja Matin nuoruudessa 1900-luvun alkuvuosikymmeninä, jolloin terveen nuoren miehen sukuvietin uskottiin olevan "paljon mahtavampi, rajumpi ja vastustamattomampi kuin norma[a]linaisen" (Forel 1911, 209). Kun nuorten miesten voimakas mutta kanavoitumaton sukuvietti yhdistyi yhteiskunnallisista muutoksista johtuvaan avioitumisiän nousuun, pelättiin seurauksena olevan riskialttiin tilanteen, jossa sukuvietti oli vaarassa saada sopimattomia ilmenemismuotoja, kuten ryhtymisen onanian harjoittamiseen. Vaikka onania nähtiin sekä miesten että naisten paheena, suurin huomio ja huoli kohdistui Eeron ja Matin kaltaisiin nuoriin miehiin, jotka pitivät konkreettisesti hallussaan tulevan sukupolven ja kansakunnan siementä (ks. Halmesvirta 1998, 190, 223).

Eeron ja Matin sairauskertomuksissa uusinnetaan avioliiton asemaa sukuvietin normatiivisena kehyksenä ja säätelijänä. Molemmat miehet asettavat avioliitossa harjoitetun seksin paheellisena pitämänsä onanian vastakohdaksi, ja aviopuolisoiden välinen sukupuolinen kanssakäyminen näyttäytyy heille seksuaalisuuden ainoana hyväksyttävänä ja tavoiteltavana kanavoitumana. Matille avioliiton solmiminen oli tietoinen keino kontrolloida aktiivisena onaniana ilmennyttä seksuaalisuutta. Matti kirjoittaa autoanamneesissaan, kuinka hän aluksi yritti tuloksetta päästä eroon onaniasta rahoittavien lääkkeiden avulla. Alkoholi pahensi tilannetta, sillä sen nauttimisesta oli Matin sanoin "seurauksena sukupuolielimeni kiihtyminen". Tämä teki onaniasta irrottautumisen entistäkin hankalammaksi. Lopulta epäonnistuneet yritykset paheen kontrolloimiseksi kypsyttivät ajatuksen avioliitosta: "Kun en saanut sukupuolielin asiaani muuten normaaliselle kannalle päätin mennä naimisiin." Avioliitto näyttäytyy kontrollin välikappaleena, jonka avulla ja jonka kehyksessä Matti toivoi "sukupuolielin asiansa" eli aktiivisena onaniana ilmenneen seksuaalisuutensa normalisoituvan. Mahdollisesti näin kävikin, tai ainakin Matti haluaa antaa ymmärtää näin käyneen, sillä kerrottuaan avioliittonsa solmimisesta ja sen jälkeisistä elämänvaiheistaan Matti ei enää kirjoita onaniasta. Hänen muistoissaan avioliitto asettuu kulminaatiopisteeksi, jonka toiselle puolelle ajoittuvat nuoruus ja aktiivisena onaniana ilmennyt kontrolloimaton seksuaalisuus. Toiselle puolelle taas asettuvat aikuisuus, lastensaanti ja hallittu seksuaalisuus, jota Matti ei muistoissaan enää käsittele.

Matti oli saanut onanian harjoittamisen hallintaansa avioitumisen avulla. Naimaton ja opintoihinsa keskittynyt Eero taas oli eräänlainen malliesimerkki kurittomasta nuoresta miehestä, jonka seksuaalisuutta avioliiton siveelliset raamit eivät vielä kontrolloineet. Sairauskertomuksesta käy kuitenkin ilmi, että myös Eeron ajattelussa mahdollinen avioituminen asettui onanian kaivatuksi kontrolloijaksi, jonka 
avulla Eero toivoi tulevaisuudessa pääsevänsä eroon syntisestä paheestaan. Eeron näkemys ilmenee hänen isänsä laatimasta, Niuvanniemen sairaalan lääkärille osoitetusta kirjeestä, jossa isä paitsi muistelee poikansa itsemurhayritystä myös esittää oman mielipiteensä pojan terveysongelmien taustasta:

Mielipiteeni mukaan on "onania" se alku josta [Eeron] hermostus on saanut alkunsa, sillä hän herkkänä ja arkaluontoisena ei ole voinut sitä kestää. Kuvaava esimerkki on kun hän joulun edellä sanoi: "häntä ei muu pelasta kuin naimisiin meno". Kyseltyäni serkuiltani lääkäreiden mielipidettä "onaniasta" sanoivat vaan, että ei sen tähden mielisairaaksi tule. Tämän johdosta kysyin häneltä [Eerolta] vähää ennen joulua, onko hän koettanut heittää pois onanian harjoittamista, vastasi siihen, että olen koettanut, sanoin siihen, luulen ettet voi sitä heittää pois, se koski häneen kipeästi, sillä hän näytti tulevan hyvin jännittyneeksi.

Sitaatti on monimerkityksinen katkelma, jossa isän, Eeron ja lääkäreiden näkökulmat kohtaavat. Isän mielestä onania oli aiheuttanut herkälle ja aralle Eerolle hermostuneisuutta, mikä myötäilee aikakauden mielisairaanhoidon diskurssia, jossa onanian uskottiin aiheuttavan hermostuneisuutta, jännittyneisyyttä ja muita lieviä psyykkisiä ja hermostollisia häiriöitä (ks. Neuman-Rahn 1924, 122-123; ks. myös Hare 1962, 9, 12-15; Hall 2003, 685-686). Isä viittaakin lääkäreinä toimiviin serkkuihinsa, joilta hän oli kysellyt professionaalia käsitystä onanian seurauksista. Lääkäriserkut olivat vähätelleet onanian merkitystä ja todenneet, että sen harjoittaminen ei voinut aiheuttaa vakavaa mielisairautta. Samassa yhteydessä isä on tehnyt kirjeen sivun alareunaan lisähuomautuksen, jonka mukaan serkut olivat niin ikään "vakuuttaneet", että onaniasta "ei voi päästä erilleen, ennen kuin naimisissa". Isän mukaan myös Eero itse oli toistanut samaa näkemystä: poika oli nimennyt avioitumisen ainoaksi ja viimeiseksi mahdollisuudekseen, joka enää voisi katkaista onanian ja tunnontuskien raskaan kierteen.

Eeron isä olisi ollut valmis hyväksymään poikansa onanian. Edellä siteeraamastani kirjeen katkelmasta on nähtävissä, että isä pyrki ikään kuin vakuuttelemaan itseään siitä, että Eeron kamppailu onanian harjoittamista vastaan oli turhaa, sillä lääkäriserkkujensa näkemykseen nojaten isä uskoi onaniasta irtaantumisen olevan naimattomalle pojalle mahdotonta. Isän ymmärtävää suhtautumista pojan onaniaa kohtaan valottaa erityisesti Eeron sairauden tilaa koskeviin huomioihin kirjattu lyhyt muistiinpano, jossa kuvataan potilaan ja hoitohenkilökunnan välillä käytyä, onanian harjoittamista koskevaa keskustelua. Oletettavasti henkilökunta tiesi Eeron taipumuksesta onaniaan ja sen aiheuttamista "tunnonvaivoista", sillä onanismi käy ilmi potilaan esitietoja kartoittaneista A- ja B-liitteistä. Laitoshoitojakson aikana asia nostettiin esille, ja Eerolta tiedusteltiin, "[o]letteko onaniaa harjoittanut". Muistiinpanosta ei selviä, viittasiko kysymys ennen laitoshoitoa vai sen aikana tapahtuneeseen onaniaan, mutta joka tapauksessa Eero oli vastannut kysymykseen myöntävästi. Tämän jälkeen hoitohenkilökunta oli jatkanut kysymällä, kuvitteliko Eero olevansa onanian vuoksi "suuri syntinen". Eeron vastaus kertoo isän ja pojan näkökulmien ristiriitaisuudesta: "Isä sanoi, että ei se [onania] mitään ole mutta - - minusta tuntuu että siinä on jotakin pahaa." Vastauksesta on nähtävissä, että isä oli yrittänyt rauhoitella poikaansa ja tämän tunnontuskia vähättelemällä onanian merkitystä. Eeron ajatteluun tällä ei kuitenkaan ollut vaikutusta. Sairauskertomukseen tehdyistä, potilaan puheita ja käyttäytymistä koskevista merkinnöistä on 
nähtävissä, että Eeron itseinho ja käsitys oman seksuaalisuuden poikkeavuudesta jatkui läpi laitoshoitojakson.

\section{Onanian patologisoinnin VastavuoroisuUs}

Onanian ja sen harjoittajien sairaalloisen poikkeavuuden konstruointi oli vastavuoroinen prosessi, joka tapahtui medikalisaatiolle luonteenomaisesti paitsi lääketieteellisten tulkintojen myös arkipuheeseen omaksutun diagnosoinnin kautta. Kriittisimmissä onanian ja mielisairauden syy-seuraussuhteen rakentumista pohtivissa tulkinnoissa on keskitytty lääketieteellisiin toimijoihin, joiden on nähty väärinkäyttäneen valta-asemaansa ja lietsoneen aktiivisesti onaniaan liittyviä pelkoja. Onanian kontrolloimiseen tähdänneet, usein kivuliaat tai vähintäänkin kiusalliset toimenpiteet on tulkittu pikemminkin potilaan rankaisuun kuin hoitoon tähtääviksi toimiksi, jotka tarkoituksellisesti ruokkivat potilaan syyllisyyttä ja sairaudentuntoa (ks. Gilbert 1975, 218-219). Onanian patologisuuden ylläpito oli taloudellisesti kannattavaa toimintaa, sillä se toi lääketieteen ammattilaisille sekä erilaisille puoskareille ja huijareille asiakkaita ja synnytti kysynnän onaniaa hillitseville rohdoksille ja välineille (Laqueur 2003, 46). Suomessa Turun Sanomissa ilmestyi vielä 1900luvun alussa mainoksia, joissa moskovalainen laboratorio kauppasi erityistä kaniinin rauhasista puristettua, parantavaa "rauhaisuutetta". Uutteen hinta oli kaksi ruplaa ja viisikymmentä kopeekkaa pullolta, ja sen luvattiin tepsivän monenlaisiin vaivoihin miehuuden puutteesta kuppaan ja vanhuuden heikkoudesta itsesaastutukseen. (Ks. esim. Turun Sanomat 10.3.1907, sivu 5.)

Onanian patologisoinnin vastavuoroisuus korostuu molemmissa sairauskertomuksissa. Erityisesti Eero oli sisäistänyt käsityksen onanian sairaalloisuudesta, mistä seurannut poikkeavuuden kokemus rapautti hänen henkistä ja fyysistä tasapainoaan. Hänen sairauskertomuksensa on kuvaava esimerkki siitä, miten usko onanian patologisuuteen aiheutti potilaalle häpeällisen ja hermostuttavan kierteen, jossa professionaalit ja henkilökohtaiset tulkinnat ruokkivat toisiaan vastavuoroisessa suhteessa. Myös Matti koki onaniansa sairaalloisena taipumuksena, mutta hänen sairauskertomuksessaan korostuu toinen itsetyydytyksen patologisointia ylläpitänyt ulottuvuus: onanian harjoittaminen uskottuine kielteisine vaikutuksineen tarjoaa Matin kokemalle poikkeavuudelle vapauttavan, ahdistusta liennyttävän selityksen. Lääketieteellisten diagnoosien määrittymiseen kytkeytyvä, ongelmia ulkoistava ja syyllisyydestä vapauttava ulottuvuus liittyy olennaisesti medikalisaatioon. Lääketieteellistymisen yhteiskunnallisia edellytyksiä tutkittaessa on esitetty, että inmiset kokevat epämukavuutta ja syyllisyyttä erilaisuudesta, jota he eivät voi luokitella esimerkiksi erityislahjaksi. Erilaisuus pyritään eliminoimaan, mutta mikäli tässä ei onnistuta, inmiset pyrkivät neutralisoimaan kokemansa epämukavuuden ja syyllisyyden lääketieteellisen diagnosoinnin kautta. Kun poikkeavuudelle määritetään lääketieteellinen syy, ihminen kykenee ottamaan etäisyyttä ongelmistaan. Diagnoosi loitontaa poikkeavuuden ihmisen henkilökohtaisista ominaisuuksista, ja siten se vapauttaa yksilön epämukavuuden ja syyllisyyden taakasta. (Tuomainen ym. 1993, 24-25; Tuomainen ym. 1999, 26.)

Vapauttava ja ongelmia ulkoistava ulottuvuus ohjaa Matin itsereflektiota onanian harjoittamisesta. Hänen autoanamneesissaan onania asettuu tiettyjä merkittäviä 
elämänvalintoja selittäväksi tekijäksi - sekä ennen kaikkea syyksi sille, miksi hän ei kyennyt vastaamaan itseensä kohdistuviin henkilökohtaisiin ja yhteiskunnallisiin odotuksiin. Matin elämä ei kaikilta osiltaan pysynyt suunnitelluissa, saati ihanteellisissa raameissa, ja kirjoittaessaan elämästään Matti asettaa onanian syyksi epäonnistumisilleen. Matti muistelee toistuvasti, kuinka onania aiheutti hänelle alati pahenevaa hermostuneisuutta, mikä johti rauhoittavien lääkkeiden käyttöön. Lääkkeet pahensivat hermostuneisuutta edelleen, mistä oli seurauksena ongelmallinen kierre, jossa eri tekijät limittyivät yhteen, kertautuivat ja ruokkivat toisiaan:

Täällä [uudessa työpaikassa] oli kuitenkin hyvin runsaasti töitä ja ennen pitkää tunsin töiden paljouden kautta hermostuvani. Käytin myös jonkin verran alkohooliaineita, mutta kun havaitsin, että alkohooliaineet eivät olleet eduksi kiihkeälle sukupuolielämälleni vähensin niiden käyttöä kunnes sitten - - en voinut niitä nauttia lainkaan, sillä sain heti kovan päänsäryn. - - [O]lin kovin hermostunut ja töitten lisäytyessä sekä perhelisäyksen tautta, kun nukkuminen jäi vähäiseksi, hermostuin taasen käyttämään runsaasti lääkkeitä, [mistä] seurauksena oli kuitenkin vain enenevä hermostumiseni.

Sitaatissa Matti muistelee avioitumisen jälkeistä elämäntilannettaan, jossa kontrolli omasta elämästä alkoi vähitellen kadota. Hän ei enää suoraan viittaa onaniaan, mutta kerronnassa ovat yhä läsnä "kiihkeän sukupuolielämän" mahdollisuus sekä hermostuneisuus, joka oli alun perin seurausta onaniasta. Edelleen Matti kirjoittaa, kuinka hermostuneisuus, uniongelmat ja väsymys pahenivat ja johtivat lopulta työssä tapahtuneeseen virhearviointiin: "[Y]lirasitetussa tilassani ja kovin hermostuneena - - en kyennyt oikein harkitsemaan tekojani." Onania kauaskantoisine vaikutuksineen asettuu Matin autoanamneesissa syyksi, jonka kautta potilas pyrkii selittämään ja ymmärtämään tekojaan. Se tarjoaa poikkeavuudelle paitsi (lääke-) tieteellisen myös potilaan itsensä hyväksymän ja hyödyntämän selityksen, jonka avulla Matti pystyy käsittelemään ja neutralisoimaan koetun poikkeavuuden aiheuttamaa ahdistustaan.

Matin sairauskertomuksessa onania on esillä ainoastaan autoanamneesissa. Muiden dokumenttien hiljaisuus onanian suhteen on kuitenkin merkityksellistä, sillä se korostaa tulkintaa siitä, että usko onanian harjoittamisen patologisuuteen tarjosi nimenomaan potilaalle itselleen omaa poikkeavuutta ja omassa elämässä tapahtuneita epäonnistumisia selittävän syyn. Kuvaavaa on, että Matin vaimo, jonka laatima kirje ${ }^{12}$ on sisällytetty Matin sairauskertomukseen, selittää monet Matin elämän merkityksellisistä käänteistä toisin kuin mies itse. Vaimo on kirjoittanut miehensä olleen "hermostunut - - siitä lähtien, kun [tämä] joutui käyttämään paljon vahvoja lääkkeitä sairauksiensa takia". Vaimon mukaan Matti ryhtyi käyttämään lääkkeitä hieman ennen avioitumista tapahtuneen, työhön kouluttautumisessa sattuneen loukkaantumisen seurauksena. Kuten edellä on käynyt ilmi, Matti itse kertoo hermostuneisuuden alkaneen jo paljon aikaisemmin, nuorena koulupoikana, jolloin hän ryhtyi onanian harjoittamiseen, mikä taas johdatti hänet rauhoittavien lääkkeiden pariin. Myös työhön kouluttautumisessa tapahtunut loukkaantuminen, johon

12 Kirjeessään Matin vaimo on vastannut miestään koskeviin kysymyksiin, joita vaimolta on tiedusteltu Niuvanniemen sairaalan taholta. Sairauskertomukseen ei sisälly tietoa esitetyistä kysymyksistä, mutta vastauksista on pääteltävissä, että vaimolta on tiedusteltu mielipidettä esimerkiksi Matin luonteenpiirteistä, käyttäytymisestä ja alkoholinkäytöstä. 
vaimokin viittaa, kytkeytyy Matin ajattelussa onaniaan. Masentuneena kyseistä tapauksesta Matti muistelee turvautuneensa alkoholiin, mikä herätti jälleen halun onanian harjoittamiseen. Seurauksena oli tuttu kierre: "Tällaisesta sukupuolielinten kiihdyttämisestä oli taasen seurauksena, että aloin käyttämään runsaasti voimakkaita lääkkeitä selviytyäkseni uudelleen kiusauksesta." Matin autoanamneesissa onania ja sen aiheuttama hermostuneisuus on toistuva, selittävä motiivi, jonka kautta potilaan kertomus ja ymmärrys omasta elämästä rakentuvat. Sen merkityksellisyys potilaalle itselleen korostuu suhteessa muissa dokumenteissa vallitsevaan hiljaisuuteen.

1700-luvun ja 1900-luvun alkuvuosikymmenten välisessä Euroopassa Matilla oli lukuisia kohtalotovereita: miehiä ja naisia, jotka uskoivat ja nimesivät onanian vaivojensa syyksi - ja jotka siten vastavuoroisesti tuottivat ja ylläpitivät onanian ja (mieli)sairauden välistä syy-seuraussuhdetta. 1800-luvulla toimineiden lääkäreiden raportteja tarkastelleen Arthur N. Gilbertin (1975) mukaan onanian määrittyminen potilaan vaivoja selittäväksi syyksi tapahtui lääkärin ja potilaan välisessä vuorovaikutuksessa, jossa potilaan rooli saattoi olla hyvinkin aktiivinen. Toisinaan potilaat kertoivat onanian harjoittamisesta kuolinvuoteellaan, mikä tarjosi sekä lääkärille että ennen kaikkea potilaalle sairautta selittävän, ymmärrettävän ja vapauttavan syyn. Vaikka onanian tunnustaminen olikin häpeällistä, epätietoisuuden sijasta oli parempi sairastaa ja kuolla tietäen ja myöntäen, mistä poikkeava tila johtui. Usein myös lapsensa menettäneet vanhemmat hakivat selitystä kuolemalle lapsen harjoittamasta onaniasta ja sen kohtalokkaista seurauksista. Vaikka lääkärit olisivatkin olleet toista mieltä, he eivät kiistäneet vanhempien selitystä, sillä korvaavia lääketieteellisiä mutta kansantajuisia selityksiä ei juuri ollut. Aikakauden lääketieteen selitysvoima erilaisille vaivoille ja ennenaikaisille kuolemille oli yhä verrattain kehittymätön. (Gilbert 1975, 225-227, 233.) Matin 1930-Iuvulla laatimassa autoanamneesissa onania asettuu edelleen poikkeavuuden kansantajuiseksi selitykseksi: yhtäältä häpeälliseksi ja kiusalliseksi mutta toisaalta ymmärrettäväksi ja vapauttavaksi diagnoosiksi, jonka määrittämisessä potilas itse oli aktiivisessa roolissa.

Myös Eeron isä toisti itsetyydytyksen ja terveyshaittojen välistä syy-seuraussuhdetta nimeämällä onanian poikansa psyykkisten ongelmien syyksi: "Mielipiteeni mukaan on 'onania' se alku josta hermostus on saanut alkunsa." Vaikka isä ei uskonut itsetyydytyksen johtavan vakavaan mielisairauteen, Eeron harjoittama onania tarjosi selityksen, jonka avulla isä pystyi ymmärtämään ja käsittelemään poikansa hermostuneisuutta ja poikkeavaa käyttäytymistä. Eeron isän ajattelussa onanian ja psyykkisten ongelmien välinen syy-seuraussuhde ei kuitenkaan ollut suoraviivainen. Isän hyväksyvässä ja itsetyydytyksen merkitystä vähättelevässä suhtautumisessa on nähtävissä viitteitä siitä, että hän oli ymmärtänyt onanian harjoittamisesta aiheutuneiden syyllisyyden ja häpeän tunteiden olevan pojan terveydelle haitallisempia kuin teko itsessään. Eeron sairauskertomukseen sisältyvien, potilaan isän näkemyksiä valottavien tekstien ja merkintöjen perusteella perimmäinen syy pojan hermostuneisuuteen löytyi isän mukaan onanian harjoittajia moralisoivasta tieteellis-yhteiskunnallisesta ilmapiiristä, joka oli aiheuttanut herkälle pojalle tunnontuskia, mikä taas oli edelleen heikentänyt tämän terveydentilaa. Eero ei kyennyt omaksumaan isänsä hyväksyvää suhtautumista onaniaan, mutta isän ajattelussa 
on nähtävissä johtolankoja verrattain uudenlaisista, itsetyydytyksen demedikalisaatiota enteilevistä tulkinnoista.

\section{MedikalisaAtion RUOHOnJUURitasolla}

Laajassa yhteiskunnallisessa mittakaavassa (mielisairaiden) itsetyydytyksen patologisointi kytkeytyi medikalisaatioon, jonka myötä valta määritellä ja kontrolloida poikkeavuutta siirtyi länsimaisten yhteiskuntien modernisoitumisen ja sekularisoitumisen myötä kirkon piiristä länsimaisen lääketieteen kentälle. Tässä artikkelissa olen kohdistanut huomioni medikalisaation ruohonjuuritasolle. Olen selvittänyt, millaisia olivat itsetyydytyksen patologisoinnin mikrotasoiset merkitykset ja miten potilaat omaisineen osallistuivat itsetyydytyksen patologisuutta koskevien tulkintojen konstruointiin.

Sekä Eero että Matti olivat sisäistäneet käsityksen onanian poikkeavuudesta suhteessa normaalina, terveenä ja soveliaana pidettyä (seksuaali)käyttäytymistä koskeviin käsityksiin. He kokivat onaniasta pidättäytymisen ihanteeksi, jonka rajoista molemmat tiedostivat livenneensä. Eerossa tietoisuus oman (seksuaali)käyttäytymisen poikkeavuudesta suhteessa kulttuurisiin ja henkilökohtaisiin odotuksiin aiheutti voimakkaan epäonnistumisen tunteen, mikä edelleen rapautti potilaan henkistä ja ruumiillista tasapainoa. Molemmat miehet toteuttivat mikrotasoista kontrollia pyrkien itse aktiivisesti säätelemään ja sanktioimaan toimintaansa - Matti lääkkeiden ja Eero itsemurhayrityksen avulla. Kummatkin asettivat myös avioliiton kontrollin keinoksi, jonka kehyksessä he toivoivat seksuaalisuutensa normalisoituvan. Kontrolloimalla ja sanktioimalla seksuaalisuuttaan potilaat tulivat samalla ylläpitäneeksi käsitystä onanian poikkeavuudesta. Heidän sairauskertomuksiaan läpäisee medikalisaatiolle luonteenomainen vastavuoroinen kierre, jossa mikrotasolle omaksutut, alun perin professionaalit tulkinnat ruokkivat yksilön uskomuksia ja pelkoja, mikä taas edelleen vahvistaa lääketieteen auktoriteettia ihmisten käyttäytymistä ja poikkeavuutta määrittävänä ja kontrolloivana instituutiona.

Itsetyydytyksen patologisoinnin vastavuoroisuus korostuu erityisesti Matin sairauskertomuksessa. Matti suhtautui onaniaansa Eeroa ulkokohtaisemmin ja analyyttisemmin käyttäen sitä poikkeavuutta selittävänä syynä, jonka avulla hän kykeni käsittelemään ja ymmärtämään elämässään tapahtuneita epäonnistumisia. Muissa sairauskertomukseen sisältyvissä dokumenteissa vallitseva hiljaisuus korostaa potilaan omaa näkemystä onanian merkityksellisyydestä. Matin sairauskertomuksessa on nähtävissä itsetyydytyksen patologisointia ja medikalisaation sosiokulttuurisia edellytyksiä edelleenkin edistävä ja ylläpitävä ulottuvuus, jossa yksilö itse osallistuu aktiivisesti vaivojensa diagnosointiin vapautuakseen poikkeavuuden aiheuttamasta epämukavuuden ja syyllisyyden taakasta. Myös Eeron isälle onania tarjosi selityksen, jonka avulla isä pystyi ymmärtämään ja käsittelemään poikansa hermostuneisuutta ja poikkeavaa käyttäytymistä.

Eeron ja Matin laitoshoitoaikana onaniaa koskevat tulkinnat olivat liikkeessä enteillen itsetyydytyksen demedikalisaatiota. Käsitys onanian yhteydestä (mieli-) sairauteen ja muihin kielteisiin seurauksiin mureni ja katosi vähitellen tultaessa 1900-Iuvun puolivälistä kohti vuosituhannen vaihdetta. Itsetyydytykseen liittyvien 
käsitysten mikrotasoinen sosiokulttuurinen murros syineen ja seurauksineen on miltei tutkimaton kenttä, mutta laajassa mittakaavassa itsetyydytyksen demedikalisaation taustaksi voidaan asettaa 1960-luvulla virinnyt seksuaalinen vallankumous, joka haastoi seksuaalimoraaliin liittyneitä perinteisiä käyttäytymismalleja sekä uskomuksia, pelkoja ja tabuja (ks. Kontula 2009, 96-97). ${ }^{13}$ Toteuttamani mikrohistoriallinen tutkimusstrategia ei mahdollista yleistysten tekemistä, mutta analysoimistani sairauskertomuksista sekä erityisesti läpikäymästäni 1930-luvun sairauskertomusten kokonaisuudesta on nähtävissä viitteitä siitä, että onanian patologisuutta koskevat tulkinnat olivat lientymässä niin makro- kuin mikrotasollakin. Erityisesti Eeron isän esittämät tulkinnat edustavat verrattain ymmärtävää näkökulmaa, sillä isä olisi ollut valmis hyväksymään poikansa onanian ymmärrettyään, että onanian harjoittamisen aiheuttamat tunnontuskat olivat Eeron terveydelle haitallisempia kuin teko itsessään.

Itsetyydytyksen patologisoinnin tarkastelu avaa lähtökohtia nykypäivänä vaikuttavan medikalisaation arvo- ja normisidonnaisuuden tiedostamiseksi. Vaikka itsetyydytys onkin demedikalisoitunut, lääketieteen ja psykiatrian asema poikkeavuutta määrittävänä ja kontrolloivana tahona ei ole kadonnut. Erityisesti mielisairaanhoidon kehyksessä käytössä olevien diagnoosien määrä on ollut jatkuvassa kasvussa. Nykypäivänä inmisellä todetaan herkästi lääketieteellistä väliintuloa vaativa ongelma, mikäli yksilö esimerkiksi lihoo toista enemmän, oppii toista hitaammin tai on muita hiljaisempi (Conrad 2007, 148-150; Pietikäinen 2013, 395). Onko tämä tarpeellista, ja millaisia seurauksia poikkeavuuden patologisoinnilla on yksilöiden elämään? Erityisesti psyykkiseen sairastamiseen liittyen toivoisin lisää tutkimusta ja julkista keskustelua medikalisaatiosta ja nykyisten diagnoosien yhteydestä normaalin, soveliaan ja ihanteellisen käyttäytymisen kulttuurisidonnaisiin määrityksiin.

Tässä artikkelissa tarkastelemani Eeron ja Matin sairauskertomukset ovat havainnollinen esimerkki medikalisaatiosta ja siitä, miten lääketieteen ja mielisairaanhoidon piirissä esitetyt tulkinnat ovat aina kulttuurisidonnaisia ja yhteydessä hyvää elämää ja ihanteellista inmisyyttä koskeviin käsityksiin. Sairauskertomukset osoittavat, että medikalisaatio on jatkuva vastavuoroinen prosessi, jossa makro- ja mikrotasoiset tulkinnat asettuvat vuorovaikutukseen ja usein myös ruokkivat toisiaan. Ennen kaikkea Eeron ja Matin sairauskertomukset ovat äärimmäisiä esimerkkejä siitä, millaisia arvottavia ja moralisoivia ulottuvuuksia medikalisaatioon liittyy ja millaisia ovat niiden ruohonjuuritasoiset, inhimilliset ja usein kipeät seuraukset.

13 Itsetyydytykseen liittyviä uskomuksia mursivat myös 1900-luvun puolivälissä ilmestyneet, amerikkalaisten seksuaalisuutta kartoittaneet ja laajan huomion herättäneet Kinseyn raportit (Kinsey ym. 1948 \& 1953). Toisin kuin oli aiemmin uskottu ja uskoteltu, raportit paljastivat itsetyydytyksen olevan erittäin yleistä, myös heteroseksuaalisissa parisuhteissa, ja lisäksi erityisesti naisten kohdalla itsetyydytyksen harjoittamisen yleisyys korreloi korkean koulutuksen kanssa. Itsetyydytyksen harjoittaja ei enää ollutkaan tietämätön ja poikkeava toinen vaan yksi meistä. (Laqueur 2003, 74.) 
Anna Kinnunen: Ongelmana onania

[http://www.elore.fi/arkisto/2_17/kinnunen.pdf]

\section{TutKimusaineisto}

Kansallisarkisto, Joensuu

Niuvanniemen sairaalan arkisto

Sairauskertomukset 1930-1939

\section{KirjallisuUs}

Ahlbeck-Rehn, Jutta 2006: Diagnostisering och disciplinering. Medicinsk diskurs och kvinnligt vansinne på Själö hospital 1889-1944. Åbo: Åbo Akademis förlag.

Ahlbeck, Jutta 2015: Ratkaisuna sterilisaatio. Kansakunnan parasiitit ja naisruumiin uhka. - Jutta Ahlbeck, Päivi Lappalainen, Kati Launis, Kirsi Tuohela \& Jasmine Westerlund (toim.), Kipupisteissä. Sairaus, kulttuuri ja modernisoituva Suomi. Turku: Utukirjat. 233-259.

Ahlbeck, Jutta, Päivi Lappalainen, Kati Launis \& Kirsi Tuohela 2013: Degeneraatio ja modernisoituva Suomi. Sairauden kulttuuristen merkitysten jäljillä. Kulttuurintutkimus 30(2): 3-15 [online]. < http://www.jyu.fi/kulttuurintutkimus/ KT 2-2013 3-15 Degeneraatio ja modernisoituva Suomi.pdf $>$ [30.3.2017.]

Barnet, Robert J. 2012: Medicalization of Life. - Canadian Dimension 46(4).

Cohen, Stanley 1985: Visions of Social Control. Crime, Punishment and Classification. Cambridge: Polity Press.

Conrad, Peter 1992: Medicalization and Social Control. - Annual Review of Sociology 18: 209-232.

Conrad, Peter 2007: The Medicalization of Society. On the Transformation of Human Conditions into Treatable Disorders. Baltimore: The John Hopkins University Press.

Conrad, Peter \& Joseph W. Schneider 1980: Deviance and Medicalization. From Badness to Sickness. St. Louis: The C. V. Mosby Company.

De Block, Andreas \& Pieter D. Adriaens 2013: Pathologizing Sexual Deviance. A History. - Journal of Sex Research 50(3-4): 276-298.

Elomaa, Hanna 2001: Mikrohistoria johtolankojen jäljillä. - Kari Immonen \& Maarit Leskelä-Kärki (toim.), Kulttuurihistoria. Johdatus tutkimukseen. Helsinki: SKS. 59-74.

Forel, August 1911: Sukupuolikysymys. Luonnontieteellinen, sielutieteellinen, terveysopillinen ja yhteiskuntatieteellinen tutkielma. Helsinki: Työväen Sanomalehti Osakeyhtiö.

Foucault, Michel 2000: Tarkkailla ja rangaista. Helsinki: Otava. [1975]

Gilbert, Arthur N. 1975: Doctor, Patient, and Onanist Diseases in the Nineteenth Century. - Journal of the History of Medicine 30(3): 217-234.

Ginzburg, Carlo 1996: Johtolankoja. Kirjoituksia mikrohistoriasta ja mikrohistoriallisesta metodista. Helsinki: Gaudeamus.

Hall, Lesley A. 1992: Forbidden by God, Despised by Men. Masturbation, Medical Warnings, Moral Panic, and Manhood in Great Britain, 1850-1950. - Journal of the History of Sexuality 2(3): 365-387. 
Hall, Lesley A. 2003: "It Was Affecting the Medical Profession". The History of Masturbatory Insanity Revised. - Paedagogica Historica 39(6): 685-699.

Halmesvirta, Anssi 1998: Vaivojensa vangit. Kansa kysyi, lääkärit vastasivat historiallinen vuoropuhelu 1889-1916. Jyväskylä: Gummerus.

Hare, E. H. 1962: Masturbatory Insanity. The History of an Idea. - The Journal of Mental Science 108(452): 1-25.

Harjula, Minna 1996: Vaillinaisuudella vaivatut. Vammaisuuden tulkinnat suomalaisessa huoltokeskustelussa 1800-luvun lopulta 1930-luvulle. Helsinki: Suomen Historiallinen Seura.

Hirvonen, Helena 2004: Mielisairauden saastuttamat. Mielisairaat perimän turmelijoina 1900-luvun alun suomalaisessa yhteiskunnassa. - Lähde - historiatieteellinen aikakauskirja 1(2): 145-160 [online]. < https://aikakauskirjalahde.files. wordpress.com/2016/04/lahde2-04.pdf > [17.10.2017.]

Hirvonen, Helena 2014: Suomalaisen psykiatriatieteen juuria etsimässä. Psykiatria tieteenä ja käytäntönä 1800-luvulta vuoteen 1930. Joensuu: Itä-Suomen yliopisto.

Illich, Ivan 1975: Medical Nemesis. The Expropriation of Health. London: Calder \& Boyars.

Jokinen, Arja, Kirsi Juhila \& Eero Suoninen 2012: Kategoriat, kulttuuri ja moraali. Johdatus kategoria-analyysiin. Tampere: Vastapaino.

Keskisarja, Teemu 2011: Kyynelten kallio. Kertomuksia seksistä ja väkivallasta. Helsinki: Siltala.

Kinnunen, Anna 2016: Onnellinen mielisairaalapotilas? Poikkeavuus ja erilaisuuden rajankäynti elokuvassa Prinsessa. - Lähikuva - audiovisuaalisen kulttuurin tieteellinen julkaisu 29(3): 24-41 [online]. < https://journal.fi/lahikuva/article/ view/59498 > [21.6.2017.]

Kinnunen, Anna \& Kirsi Hänninen 2016: Saatteeksi. Hulluus kulttuurisena ilmiönä ja tutkimuskohteena. - Elore 23(1) [online]. < http://www.elore.fi/elore-12016vol-23-hulluus/saatteeksi-hulluus-kulttuurisena-ilmiona-ja-tutkimuskohteena/ $>$ [9.2.2017.]

Kinsey, Alfred C., Wardell B. Pomeroy \& Clyde E. Martin 1948: Sexual Behavior in the Human Male. Philadelphia: Saunders.

Kinsey, Alfred C., Wardell B. Pomeroy, Clyde E. Martin \& Paul H. Gebhard 1953: Sexual Behavior in the Human Female. Philadelphia: Saunders.

Kirkebæk, Birgit 2005: Sexuality as Disability. The Women on Sprogø and Danish Society. - Scandinavian Journal of Disability Research 7(3-4): 194-205.

Kitsuse, John I. 1962: Societal Reaction to Deviant Behavior. Problems of Theory and Method. - Social Problems 9(3): 247-256.

Kontula, Osmo 2009: Between Sexual Desire and Reality. The Evolution of Sex in Finland. Helsinki: Väestöliitto.

Koski, Kaarina 2016: Yliluonnollista vai patologista? Kummien kokemusten muuttuvat tulkinnat. - Elore 23(1): 1-22 [online]. < http://www.elore.fi/arkisto/1_16/ koski.pdf $>$ [15.2.2017.] 
Laqueur, Thomas W. 2003: Solitary Sex. A Cultural History of Masturbation. New York: Zone Books.

Levi, Giovanni 1991: On Microhistory. - Peter Burke (ed.), New Perspectives on Historical Writing. Cambridge: Polity Press. 93-113.

MacDonald, Robert H. 1967: The Frightful Consequences of Onanism. Notes on the History of Delusion. - Journal of the History of Ideas 28(3): 423-431.

Mattila, Markku 1999: Kansamme parhaaksi. Rotuhygienia Suomessa vuoden 1935 sterilointilakiin asti. Helsinki: Suomen Historiallinen Seura.

Neuman-Rahn, Karin 1924: Sielullisesti sairas ihminen ja hänen hoitonsa. Helsinki: WSOY.

Neuman, R. P. 1975: Masturbation, Madness, and the Modern Concepts of Childhood and Adolescence. - Journal of Social History 8(3): 1-27.

Peltonen, Matti 1999: Mikrohistoriasta. Helsinki: Gaudeamus.

Pietikäinen, Petteri 2013: Hulluuden historia. Helsinki: Gaudeamus.

Rantala, Pälvi 2009: Erilaisia tapoja käyttää kylähullua: Kalkkimaan pappi aatteiden ja mentaliteettien tulkkina 1800-luvulta 2000-luvulle. Turku: K\&H-kustannus.

Rissanen, Anu 2017: Henkilökohtainen tiedonanto historiantutkija Anu Rissaselta. Sähköposti artikkelin kirjoittajalle 11.5.2017.

Saarinen, Tuija 2003: Poikkeusyksilö ja kyläyhteisö. Tutkimus Heikan Jussin (Juho Mäkäräisen) elämästä ja huumorista. Helsinki: SKS.

Salo, Markku 1996: Sietämisestä solidaarisuuteen. Mielisairaalareformit Italiassa ja Suomessa. Tampere: Vastapaino.

Stall, Sylvanus 1928: Mitä pojan tulee tietää. Helsinki: Kustannusosakeyhtiö Kirja.

Suoninen, Marja 2001: Mikrohistoria vastauksena historiallisen sosiologian dilemmaan. - Sosiologia 38(1): 14-26.

Tuomainen, Raimo, Markku Myllykangas \& Jyrki Elo 1993: Medikalisaatio. Terveyden mielikuvin kohti menestystä. - Sosiaalinen aikakauskirja 87(5): 22-28.

Tuomainen, Raimo, Markku Myllykangas, Jyrki Elo \& Olli-Pekka Ryynänen 1999: Medikalisaatio. Aikamme sairaus. Tampere: Vastapaino.

Ussher, Jane M. 2012: The Madness of Women. Myth and Experience. New York: Routledge.

Van Driel, Mels 2012: Kädellä. Itsetyydytyksen historia. Helsinki: Finn Lectura.

Vuorio, Kaija 2010: Niuva. Niuvanniemen sairaala 1885-1952. Kuopio: Niuvanniemen sairaala.

Wretlind, E. W. 1893: Miesten siitinelo säännöllisessä ja kivulloisessa tilassa. Helsinki: WSOY.

Zola, Irving Kenneth 1972: Medicine as an Institution of Social Control. - The Sociological Review 20(4): 487-504.

Filosofian maisteri Anna Kinnunen valmistelee psyykkisesti sairastaviin ihmisiin kytkeytyviä kulttuurisia käsityksiä tarkastelevaa perinteentutkimuksen väitöskirjaa Itä-Suomen yliopistossa. 